\title{
EVALUATION, RADIOACTIVITY AND MECHANICAL ANALYSIS OF THE TOP METER BLACK SANDS NORTH EAST OF MOTOBAS INDUSTERIAL SECTOR, KAFR AL-SHEIKH GOVERNORATE, EGYPT.
}

EL-AFANDY, A. H., MOUSTAFA, M.I., EL NAHAS, H.A., ABDOU, A.A. AND BARAKAT, M.G.

Nuclear Material Authority, P.O. Box 530 Maadi, Cairo, Egypt.

\begin{abstract}
The coastal plain of study area covered by sea water rich in fines derived from the clay lenses of the continental shelf by erosion process comprises three zones; eastern, middle and western. So, the high content of fines varies from $0.72 \%$ to 74.08 with an average of $18 \%$. The apparent specific gravity of topmost part of the sands one meter thick varies from $1.29 \mathrm{~g} / \mathrm{cm}^{3}$ to $1.74 \mathrm{~g} / \mathrm{cm}^{3}$ with an average of $1.59 \mathrm{~g} / \mathrm{cm}^{3}$. The studied sediments are derived from river environment, due to the high content of clay and organic matter in the raw sands. The average percentage of sand fraction finer than 125 micron has an average value of $19.51 \%$, in which the total heavy fractions constitutes 92.78 $\%$ in average of its total amounts.

The calculated total reserve of the economic heavy minerals reaches up to 578,760 tons separated from 2893.800 tons bulk sands. Its mineral constituents are; 182,850 tons magnetite, 329,130 tons ilmenite, 23,850 tons garnet, 14,310 tons leucoxene, 20,670 tons zircon, 6,996 tons rutile and 954 tons monazite.

The radiometric measurements of the study area revealed that the western zone which occupies four square kilometers have high values of specific activity, absorbed and effective doses because of its high contents of monazite and radioactive zircon, while the eastern and middle zones each occupy three square kilometers posses a moderate to low values of these activities respectively. Therefore, the the western zone is not recommended as building materials because of its relatively high radioactivity. Meanwhile, sands of the middle and eastern zones are recommended for the same target, after separation the economic and strategic minerals of strategic importance.
\end{abstract}

\section{INTRODUCTION}

The Egyptian black sand placer deposits are discontinuously distributed along the northern coastal plain of the Nile Delta and Sinai Peninsula, i.e. in the coastal zone between Abu Qir to the west and Rafah to the east (about $300 \mathrm{Km}$ long). These deposits contain strategic and economic heavy minerals, which are needed either for nuclear industry or other metallurgical and engineering industries.

The mineralogy of the Egyptian black sands was studied previously by many workers. The most recent of which are Dabbour (1994,1997), Dewedar (1997), Moustafa (1999), El-Nahas (2002), Barakat (2004), Abu Halawa (2005), Abdel Fattah (2008), Abu Diab (2008), Moustafa $(2007,2009,2010)$ and El-Shafey (2011).

The Egyptian black sands along the Mediterranean Sea Coast are known for their enhanced natural radiation environment, due to the presence of the radiogenic heavy minerals as monazite, radioactive zircon, thorite and uranothorite. The radioactive measurements serve as a tracer in exploration for the heavy radioactive and other economic minerals. The radioactivity of the Egyptian black sands was recently studied by Sadek et al. (1990), ElGamal et al. (2004), Saleh et al. (2004), Ammar et al.(2005), Naser et al. (2006), El-Gamal and Saleh (2012).
The grade and reserves of the economic heavy minerals in the Egyptian black sands are appreciably high compared to other similar major world occurrences (Hammoud, 1966). Early pre the year 1952, the Egyptian black sands at Abu Khashaba area were subjected to extensive exploration. Later, several evaluation attempts of the total economic minerals or with one or more of the six heavy economic minerals. by different authorities and organizations, of these El-Shazly (1965), Dabbour (1973,1980), Hammoud (1985), Robertson Research International (RRI) limited company (1985), Dabbour (1994), El-Hadary (1998), Abdel-Fattah (2008), El-Shafey (2011)

Recently, Nuclear Materials Authority (NMA) constructed a pilot industrial plant for the exploitation of the black sands at Rosetta town and Abu-Khashabah village to the east of Rosetta. For the completion and continuation of this plant to extract the economic heavy minerals on industrial scale, near and accessible area of high potentiality far from marine erosion and human activity is required for further expansion of this production line. So, the present study deals with results of the evaluation studies of the topmost meter of the black sands accumulations north east of Motobas industrial sector, Kafr Al- Sheikh Governorate, Egypt.

The study area covers an area of about $10 \mathrm{Km}^{2}$, with $10 \mathrm{Km}$ long parallel to the 
shoreline and one kilometer width nearly perpendicular to the shoreline (Fig. 1). The study area bounded by the international highway to the south, Abu-Khashabah lighthouse asphalted road to the west and ElSahel (coastal) drain to the north. So, it can be reached by cars along a suitable asphaltic roads which connected it by the main towns and sea ports for export.

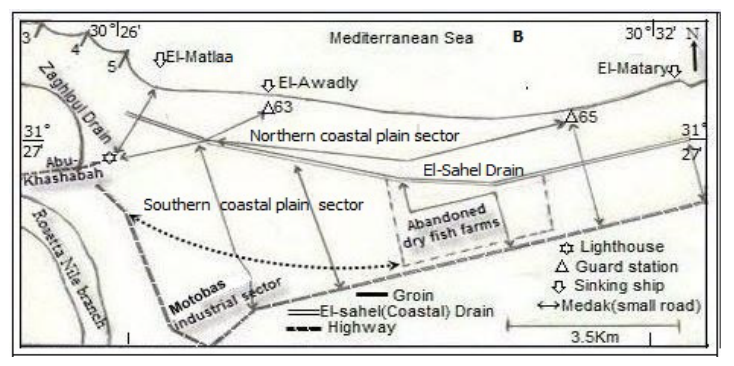

Fig. 1: Location and accessibility of the study area.

\section{GEOMORPHOLOGY OF THE}

\section{STUDY AREA.}

The study area is a wide coastal plain characterized by the absence of wind ripple marks due to the coherent of the surface sand by salts, clay and organic matter. In winter season, with drop out of fresh water, the south-eastern sector of the study area characterized by flourishing of bushes, reeds, and grasses in slightly elevated areas, Fig. (2), with death and disintegration of these plants in summer season, the organic matter increased annually in the top meter of the beach sediments. Also in winter season and during stormy condition the sea water carried clay and dissolved materials as a result of marine erosion of clay lenses of the continental shelf covered the low areas of AbuKhashabah coastal plain especially the study area until the international coastal highway, Fig. (3). In summer season, with the evaporation of sea water and the formation of salt crusts, some pockets of study area was utilized in non domestic salt production.
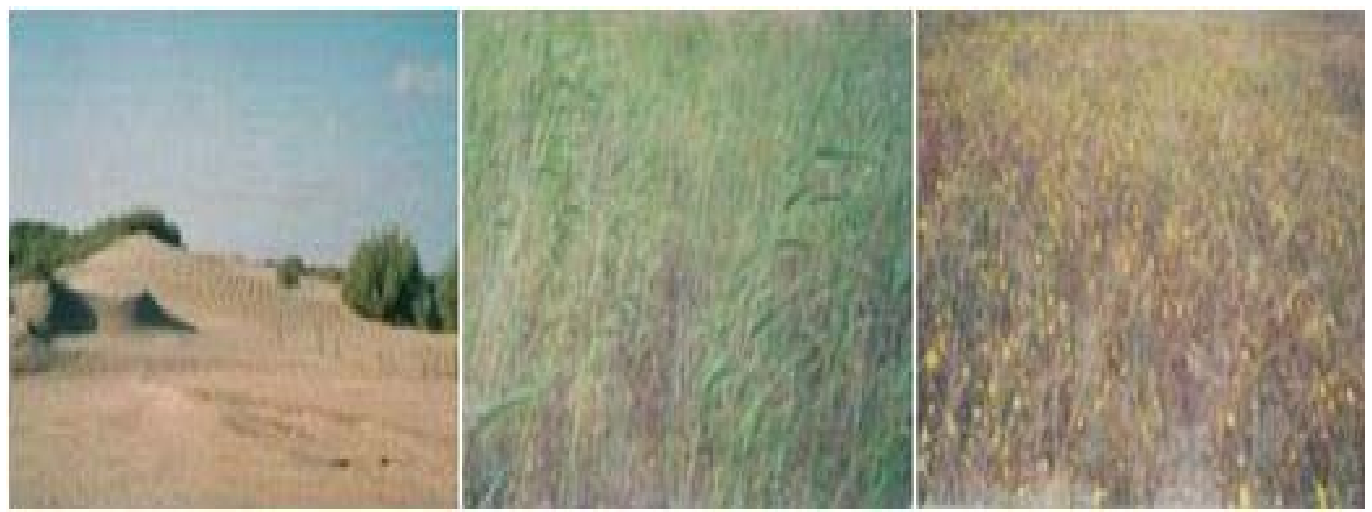

Fig. (2): Photographs showing flourishing of bushes, reeds, and grasses in the south-eastern sector of the study area.

Also, the southern sector of coastal plain of the study area is characterized by the distribution of seepage of clay and organic matter in some low elevated areas, Fig. (4).

\section{SAMPLING AND TECHNIQUES}

\section{III.1. Sampling}

The size of samples to be collected in any case depends mainly upon two considerations; the coarseness of the sediments and the uses to which the sample is to be used, Krumbein and Pettijohn (1938).

The sampling of the topmost meter of the sands depends on the moisture of the sand which aids in hosting the sand in the sampler holder. Each wetted sample was collected till the entire sample holder goes one meter thick in the sediment and repeated. The coastal plain area was covered by 306 samples to a depth of one meter due to a grid pattern $200 \mathrm{~m} \times 200 \mathrm{~m}$ (Fig. 5).

\section{III.2. Radiometric Measurements.}

In the study area, spectral gamma-ray measurements have been conducted using a portable gamma-ray multi-channels spectrometer, manufactured by Geofyzika Brno, Czech Republic, model GS-512. According to sampling grid pattern of the study area $(200 \mathrm{~m} \mathrm{X}$ $200 \mathrm{~m}), 306$ measured sites were obtained along the profiles (A, B, C, D, E \&F). The radiometric measurements for $\mathrm{K}(\%), \mathrm{U}(\mathrm{ppm})$ and $\mathrm{Th}$ (ppm) were obtained at each of the measured stations. The measuring time was set at 30 seconds to permit the accumulation of the gamma-ray emission. The data were directly stored in the field and entered daily to a personal computer as a text file for additional processing. 

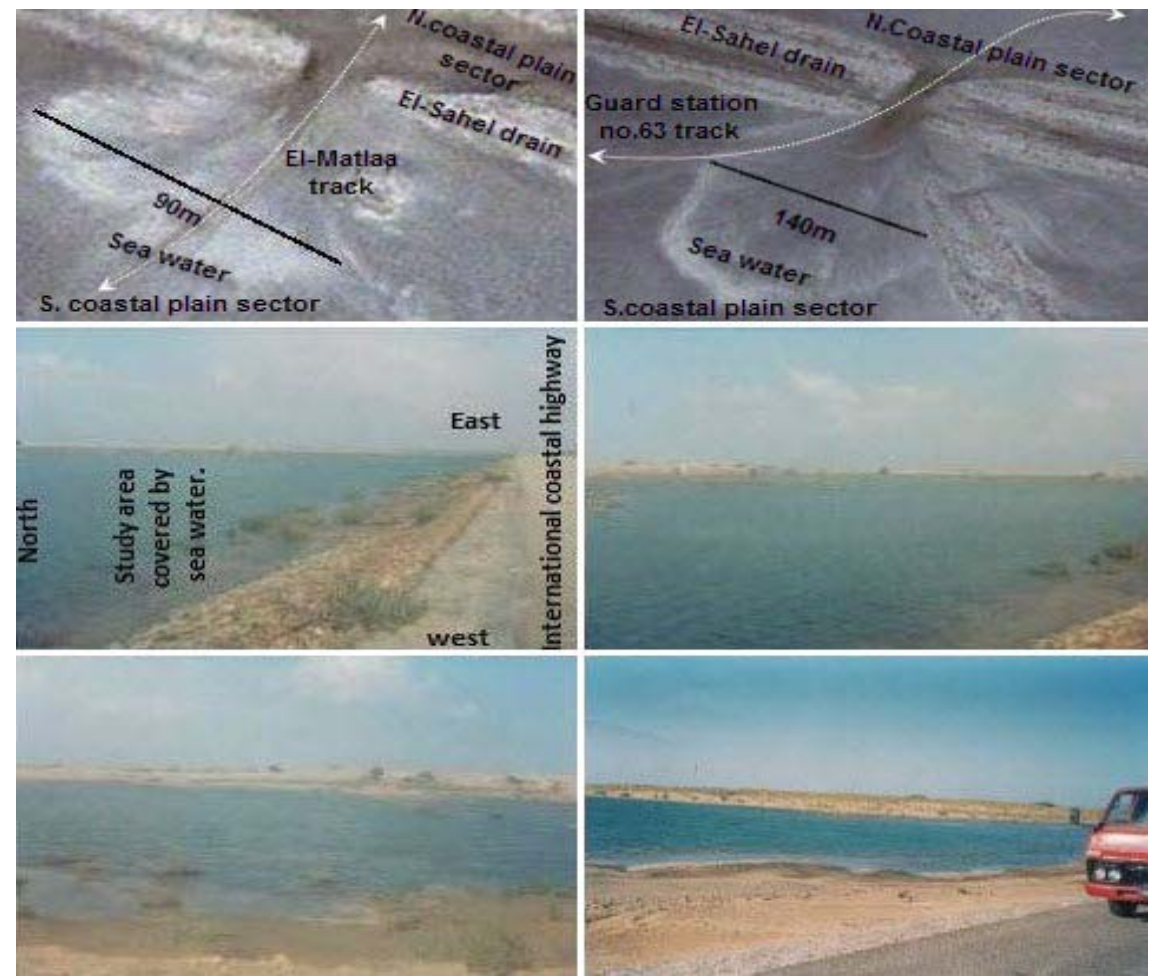

Fig. (3): (a\&b) Satellite images and photographs photos (c, d, e and f) showing southern coastal plain area covered by sea water during winter season.

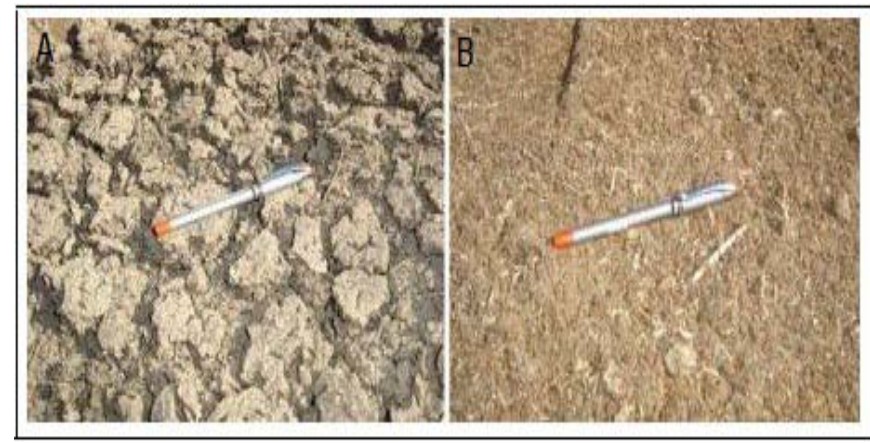

Fig. (4): a) Photographs showing mud cracks, and b) organic matter distributed in low land.

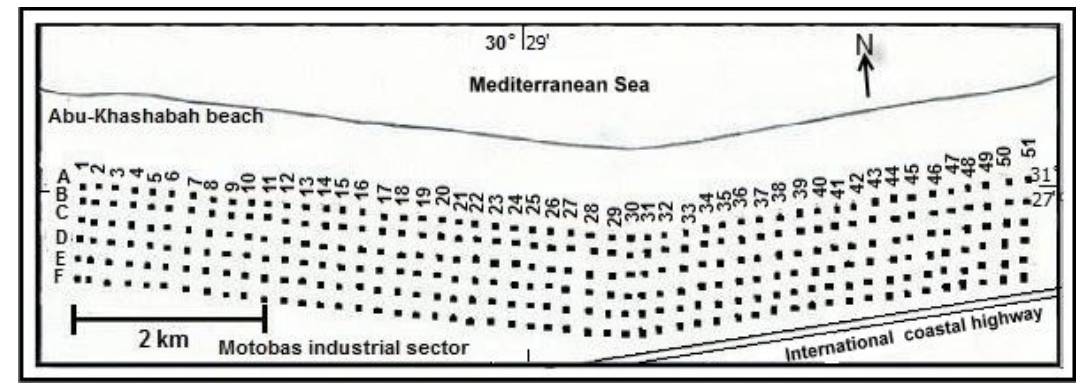

Fig. (5): location map showing the field distribution of the collected samples.

\section{III.3. Sample Preparation.}

Each collected sample, weighing about $11 \mathrm{Kg}$, was subjected to sun drying and disaggregation process. Each dry sample was splitted repeatedly using John's Splitter till a representative sample weighing about 200 gram was obtained while the rest returned to the stored sample. Each representative sample was weighed and put in a two liter size beaker filled with water and subjected to electric stirring for about 5 minutes to liberate the different particles composing the sample. Then, the sample was left to rest for a time suitable to settle all sizes larger than fine silt size. The upper two-thirds of the water depth with its suspended materials were decanted using a siphon to avoid the 
escape of any sand particle during decantation. The process was repeated several times till the decanted water becomes clear. The organic mater content in each washed sample was leached by adding hot hydrogen peroxide (3\%). Each clean sample after drying was weighed. The difference between the first weight of each sample and its weight after cleaning represents the weight of the fines (the weight of the size fraction, the coarse silt size and the organic matters).

III.4. Calculation of the apparent specific gravity

Actually, the apparent specific gravity reflects the heavy minerals content as well as the grain size of the deposit (Dabbour 1991). Each field sample was dried carefully and a representative sample (1-2 Kg.) was taken by using of John's splitter. Each representative sample was weighted and slowly poured inside a calibrated cylinder and compacted very well by shaking to be analogous to the field deposit. The weight of the sand was divided by its volume to obtain the apparent specific gravity.

\section{III.5. Grain size analysis}

A representative sample weighing 50 grams was screened using an automatic vibratory shaker for about 30 minutes. The retained material on each sieve and in the pan was taken and weighed and the frequency for each size was calculated.

\section{III.6. Mineralogical investigations.}

Representative samples weighing about 40 grams from the 306 previously prepared samples were subjected to heavy minerals separation using Bromoform $\left(2.8 \mathrm{gm} / \mathrm{cm}^{3}\right)$ and Clerici's solution $\left(3.7 \mathrm{gm} / \mathrm{cm}^{3}\right)$. The obtained heavy fractions from the Bromoform separation (the total heavy minerals) were subjected to Clerici's solution separation in order to separate the heavy economic minerals (magnetite, ilmenite, leucoxene, zircon, rutile, garnet, monazite and other trace economic heavy minerals in the sink layer or heavy sub-fraction and the coloured silicates in the float subfractions.

Each of the economic minerals exhibits its own magnetic susceptibility, which varies from ferromagnetic to non-magnetic minerals. The magnetic fractionation can help in the differentiation between some heavy minerals during the microscopic examination.

Magnetite grains (ferromagnetic mineral) must be firstly removed from each heavy subfraction with a hand magnet or by the using of Frantz, Ferro-filter Magnetic Separator. The magnetite free heavy sub-fractions were subjected to magnetic fractionation using the Frantz Isodynamic Separator modal, (L-1). The selected electric current for the separation are
$0.2,0.5,1.0$ and 1.5 ampere. These magnetic field strengths were chosen to separate the opaque particles into three sub-fractions; ilmenite particles in the highly magnetic subfraction, altered ilmenite in the next magnetic sub-fraction and the rest opaque particles represent opaque rutile (Dabbour, 1995). Also, the magnetic fractionation used to separate monazite from zircon particles into two different magnetic sub-fractions. So, five magnetic sub-fractions from each heavy part were obtained which are the magnetic subfraction at 0.2 ampere, the magnetic subfraction at 0.5 ampere, the magnetic subfraction at 1.0 ampere, the magnetic subfraction at 1.5 ampere and the non-magnetic sub-fraction at 1.5 ampere.

Each free magnetite sub-fraction was subjected to microscopic examination to identify and count the different heavy economic minerals using the binocular stereomicroscope and transmitted polarizing light microscope. A representative sufficient amount of minerals particles was taken by quartering from each magnetic sub-fraction and sprinkled on a glass slide, to be ready for the microscopic investigation. About 1000 mineral particles were identified and counted, from different microscopic fields covering the entire prepared slide and the frequency of each mineral present in the slide was calculated.

\section{RESULTS}

\section{IV.1. Apparent specific gravity}

Minimum, maximum and average values of apparent specific gravity along six profiles parallel to the shoreline in the study area was calculated. The average values of apparent specific gravity of field samples along ten square kilometers and three zones arranged from west to east as well as in the western and eastern halves of the study area was estimated and tabulated in Table (1).

\section{IV.2. Grain size distribution}

The grain size analysis of detritus composing sediment is a useful tool in the nomenclature of the sediments, recognizing the environment of deposition and the prevailing hydrodynamic conditions during and after deposition (Passega, 1964; Passega and Byramjee, 1964 and Pettijohn, 1975). It is also used in the recognition of the three fundamental modes of sediment transportation, which are surface creep, saltation and suspension, (Inman, 1949; Mason and Folk, 1958; Friedman, 1961\&1967; Shepard and Young, 1961; Sahu, 1964; Martin, 1965; Sevon, 1966; Moiola and Weiser, 1968; Visher, 1969; Nordstrom, 1977; Rajamanickam and Gujar, 1984, 1997). Pettijohn (1975) concluded that, the coarser grains being a 
product of traction transport whereas the finer grains being the result of saltation or suspension transport.

Table (1): The average values of apparent specific gravity of field samples along ten square kilometers and three zones arranged from west to east as well as in the western and eastern halves of the study area.

\begin{tabular}{|c|c|c|c|c|}
\hline \multirow{2}{*}{ Area } & \multirow{2}{*}{ Zone } & \multicolumn{3}{|c|}{$\begin{array}{c}\text { Average apparent specific } \\
\text { gravity }\end{array}$} \\
\hline & & Av.Sp.Gr & zone & Average \\
\hline $1^{\text {st }}$ & \multirow{4}{*}{ Western } & 1.60 & \multirow{4}{*}{1.62} & \multirow{10}{*}{1.59} \\
\hline $2^{\text {nd }}$ & & 1.62 & & \\
\hline $3^{\text {rd }}$ & & 1.62 & & \\
\hline $4^{\text {th }}$ & & 1.62 & & \\
\hline $5^{\text {th }}$ & \multirow{3}{*}{ Middle } & 1.61 & \multirow{3}{*}{1.58} & \\
\hline $6^{\text {th }}$ & & 1.58 & & \\
\hline $7^{\text {th }}$ & & 1.55 & & \\
\hline $8^{\text {th }}$ & \multirow{3}{*}{ Eastern } & 1.57 & \multirow{3}{*}{1.59} & \\
\hline $9^{\text {th }}$ & & 1.59 & & \\
\hline $10^{\text {th }}$ & & 1.60 & & \\
\hline
\end{tabular}

The traction mode of transportation is greatly affected on the size, shape and surface texture of the transported sediments whereas suspension mode has less effect. The coarse grains apparently become better rounded and more spherical as a result of abrasion during transportation than the finer grains.

Grain size analysis and screening process can be considered a physical dressing tool in the concentration of the economic heavy minerals in a defined size grade, (Barakat, 2004), because the economic minerals of placer deposits are mostly more heavier and more fine than the associated gangue minerals. Grain size is an important factor in concentration and separation of economic heavy minerals using wet gravity, electrostatic and magnetic processes during exploitation of black sand, (Lawver et al., 1986; Burt, 1984; Kelly and Spattiswood, 1989 and Moustafa, 1999). Also, the grain size of mineral grains is important in metallurgy, chemical treatments and manufacture of paints, pigments and abrasives.

During exploitation of the black sand deposits, the presence and distribution of fines (sizes finer than the coarse silt and organic materials) is an important parameter, where these materials cause many problems during mining processes of the beach placers.

The average values of fines percentage of field samples along ten square kilometers and three zones arranged from west to east as well as in the western and eastern halves of the study area was estimated and tabulated in Table (2).

Table (2): The average values of fines percentage of field samples along ten square kilometers and three zones arranged from west to east as well as in the western and eastern halves of the study area.

\begin{tabular}{|c|c|c|c|c|}
\hline \multirow[t]{2}{*}{ Area } & \multirow[t]{2}{*}{ Zone } & \multicolumn{3}{|c|}{ Average values of fines } \\
\hline & & Av. $(W t \%)$ & zone & Average \\
\hline $1^{\text {st }}$ & \multirow{4}{*}{ Western } & 21.04 & \multirow{4}{*}{18.37} & \multirow{10}{*}{18.00} \\
\hline $2^{\text {nd }}$ & & 16.25 & & \\
\hline $3^{\text {rd }}$ & & 19.34 & & \\
\hline $4^{\text {th }}$ & & 16.85 & & \\
\hline $5^{\text {th }}$ & \multirow{3}{*}{ Middle } & 19.03 & \multirow{3}{*}{15.21} & \\
\hline $6^{\text {th }}$ & & 13.68 & & \\
\hline $7^{\text {th }}$ & & 12.92 & & \\
\hline $8^{\text {th }}$ & \multirow{3}{*}{ Eastern } & 19.25 & \multirow{3}{*}{20.11} & \\
\hline $9^{\text {th }}$ & & 21.14 & & \\
\hline $10^{\text {th }}$ & & 19.93 & & \\
\hline
\end{tabular}

The eastern zone contains the highest fines percentage (20.11\%) compared with the middle $(15.21 \%)$ or the western one $(18.37 \%)$. The highest fines percentage $(21.14 \%)$ located at the ninth kilometer sediment whereas the lowest value $(12.92 \%)$ located at the seventh kilometer sediment.

The average values of the grain size distribution of the field samples along the six profiles parallel to the shoreline (A, B, C, D, E and $\mathrm{F}$ profiles) are shown in Table (3) and graphically represented by histograms, Fig. (6).

The histograms representing the grain size distribution of the field samples along the six profiles parallel to the shoreline (A, B, C, D, E and $\mathrm{F}$ profiles) indicate that, the modal class lying in the fine sand size $(250 \mu-125 \mu)$.The weight percent of the modal class (fine sand fraction) ranges from $54.80 \%$ to $61.02 \%$ with an average $58.42 \%$. The profiles, $\mathrm{A}$ and $\mathrm{B}$ show unimodal distribution, whereas profiles $\mathrm{C}, \mathrm{D}, \mathrm{E}$ and $\mathrm{F}$ show bimodal distribution. 
Table (3): The average values of the grain size distribution of the field samples along six profiles parallel to the shoreline (A, B, C, D, E and F).

\begin{tabular}{|c|c|c|c|c|c|c|}
\hline \multirow[b]{3}{*}{ profile } & \multicolumn{6}{|c|}{ Grain size analysis of field samples } \\
\hline & \multirow{2}{*}{$\begin{array}{c}\text { Fines } \\
(\%) \\
\end{array}$} & \multicolumn{5}{|c|}{ Grain size analysis, (Wt \%) } \\
\hline & & $+500 \mu$ & $+250 \mu$ & $+125 \mu$ & $+63 \mu$ & $<63 \mu$ \\
\hline $\mathbf{A}$ & 12.23 & 0.64 & 7.57 & 61.02 & 17.89 & 0.64 \\
\hline B & 15.41 & 0.32 & 7.01 & 59.94 & 16.85 & 0.47 \\
\hline $\mathbf{C}$ & 16.37 & 0.45 & 7.62 & 60.37 & 14.71 & 0.49 \\
\hline D & 23.15 & 0.39 & 6.4 & 55.63 & 14.08 & 0.34 \\
\hline $\mathbf{E}$ & 17.36 & 0.37 & 7.23 & 58.75 & 15.91 & 0.38 \\
\hline F & 23.49 & 0.34 & 7.04 & 54.80 & 13.87 & 0.46 \\
\hline Average & 18.00 & 0.42 & 7.15 & 58.42 & 15.55 & 0.46 \\
\hline
\end{tabular}

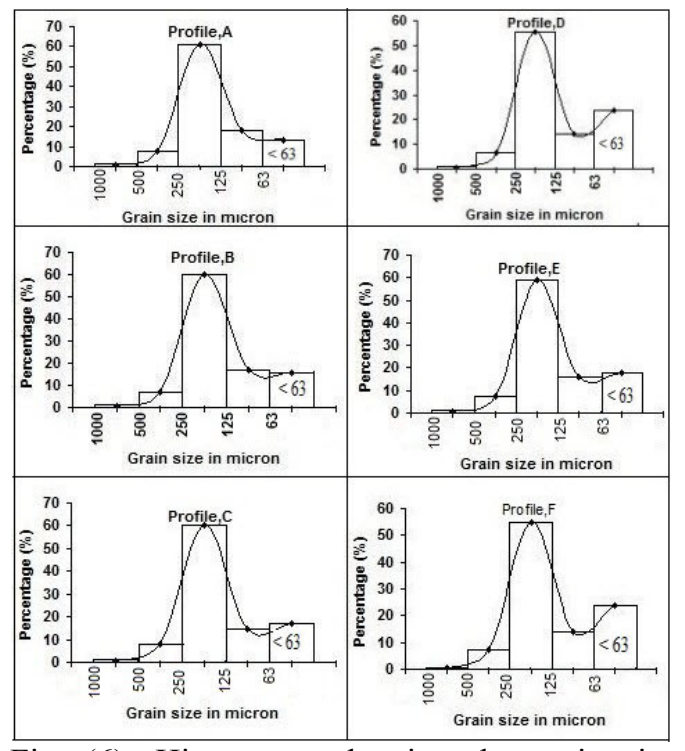

Fig. (6): Histograms showing the grain size distribution of field samples along six profiles parallel to the shoreline.

The different grain size parameters were classified into different classes and the results are shown in Table (4). The mean size (Mz) of the raw sand sediments concentrated in two classes, the fine sand size class $(50.98 \%)$ and the very fine sand size class $(49.02 \%)$. The Inclusive graphic standard deviation, sorting $(\sigma 1)$, showed that most of the studied field samples located in the moderately sorted class
$(94.12 \%)$ whereas $5.88 \%$ located in the moderately well sorted class. The Inclusive graphic Skewness, $(S k 1)$, showed that most of the studied field samples located in the Extremely Fine Skewed (88.24\%) whereas 11.76 $\%$ located in the Strongly Fine Skewed class. The graphic kurtosis, $\left(K_{\mathrm{G}}\right)$ of the studied field samples distributed in four classes with a modal class located in the leptokurtic class $(56.86 \%)$, whereas $23.53 \%$ located in the mesokurtic class and $11.76 \%$ located in the very leptokurtic class.

Some bivariant relations between grain size parameters are graphically represented in Fig. (7), these relations indicate that, the studied sediments fall in the river environment, due to the high content of clay and organic matter in the raw sands.

The average values of the grain size distribution of the sand fractions along six profiles parallel to the shoreline (A, B, C, D, E and $\mathrm{F}$ profiles) are shown in Table (5) and graphically represented by histograms and frequency curves (Fig. 8).

The histograms and frequency curves representing the grain size distribution of sand fractions along the six profiles parallel to the shoreline (A, B, C, D, E and F profiles) indicate unimodal distribution, where the modal class lying in the fine sand size $(250 \mu-125 \mu)$.The weight percent of the modal classes ranges from $69.55 \%$ to $72.17 \%$ with an average $71.31 \%$. 
Evaluation, Radioactivity And Mechanical Analysis Of The Top

Table (4): Distribution of different calculated grain size parameters among different classes.

\begin{tabular}{|c|c|c|c|c|c|c|c|}
\hline \multicolumn{2}{|c|}{$\begin{array}{c}\text { Mean size } \\
\text { (Mz) }\end{array}$} & \multicolumn{2}{|c|}{$\begin{array}{c}\text { Sorting } \\
(\sigma 1)\end{array}$} & \multicolumn{2}{|c|}{$\begin{array}{c}\text { Skewness } \\
\text { (Sk1) }\end{array}$} & \multicolumn{2}{|c|}{$\begin{array}{c}\text { Kurtosis } \\
\left(\mathbf{K}_{\mathrm{G}}\right)\end{array}$} \\
\hline Class & $\%$ & class & $\%$ & class & $\%$ & class & $\%$ \\
\hline 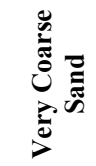 & --- & 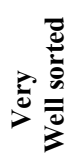 & -- & 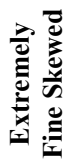 & $\begin{array}{c}88.2 \\
4\end{array}$ & $\frac{0}{\partial}$ & --- \\
\hline 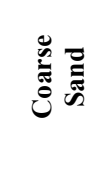 & --- & 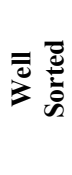 & -- & 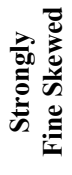 & $\begin{array}{c}11.7 \\
6\end{array}$ & 突 & 7.84 \\
\hline 声 & --- & 물 & & 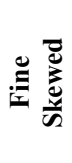 & -- & 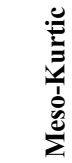 & 23.53 \\
\hline 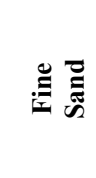 & 50.98 & $\sum_{\bar{z}}^{2}$ & 5.88 & 党 & -- & 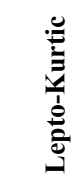 & 56.86 \\
\hline 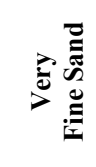 & 49.02 & 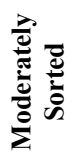 & 94.12 & 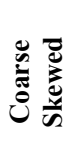 & -- & 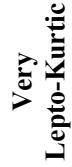 & 11.76 \\
\hline
\end{tabular}

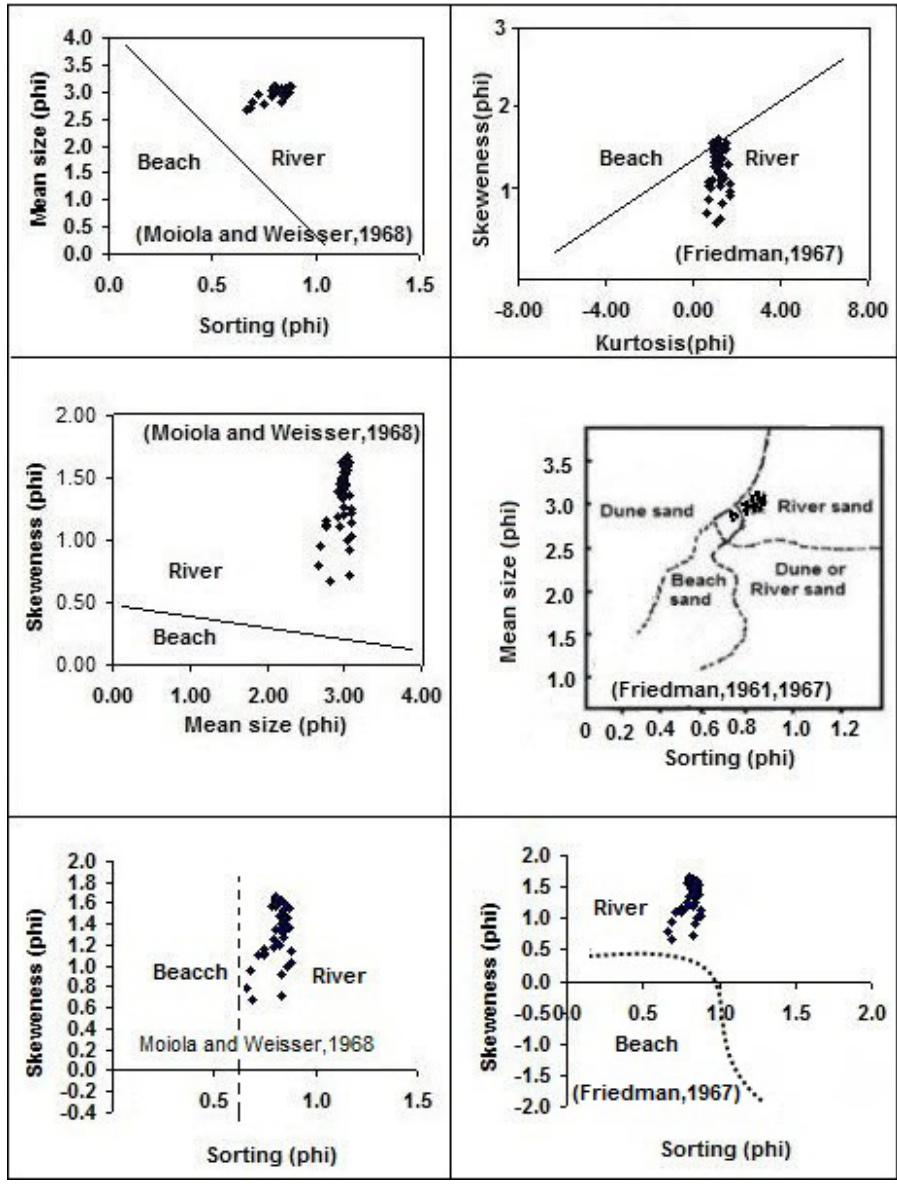

Fig. (7): Bivariant relations between grain size parameters to determine sedimentary environments 
Table (5): The average values of the grain size distribution of sand fractions along six profiles parallel to the shoreline (A, B, C, D, E and F).

\begin{tabular}{|c|c|c|c|c|c|}
\hline \multirow{3}{*}{ Profiles } & \multicolumn{5}{|c|}{ Grain size distribution of sand fraction,(wt \%) } \\
& & & & \\
\cline { 2 - 6 } & $+500 \mu$ & $+250 \mu$ & $+125 \mu$ & $+63 \mu$ & $-63 \mu$ \\
\hline A & 0.73 & 8.63 & 69.55 & 20.37 & 0.72 \\
\hline B & 0.38 & 8.26 & 70.97 & 19.84 & 0.56 \\
\hline C & 0.53 & 9.05 & 72.17 & 17.68 & 0.58 \\
\hline D & 0.51 & 8.30 & 72.50 & 18.24 & 0.44 \\
\hline E & 0.44 & 8.72 & 71.13 & 19.26 & 0.45 \\
\hline F & 0.45 & 9.07 & 71.56 & 18.30 & 0.62 \\
\hline Av. & 0.46 & 8.67 & 71.31 & 18.95 & 0.56 \\
\hline
\end{tabular}

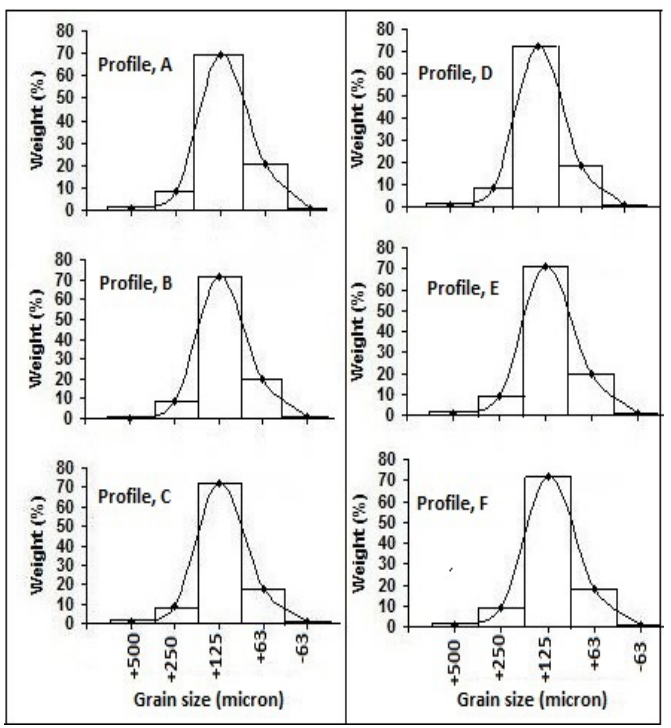

Fig. (8): Histograms and frequency curves showing the grain size distribution of sand fractions along six profiles parallel to the shoreline.

The different grain size parameters were classified into different classes and the results are shown in Table (6). The mean size (Mz) of the sand fractions have average $2.60 \Phi$ and the modal class located in the fine sand size class (100 \%). The Inclusive graphic standard deviation, sorting $(\sigma 1)$ has an average $0.49 \Phi$, and the modal class located in the well sorted class $(51 \%)$ whereas $47 \%$ located in the moderately well sorted class and $2 \%$ located in the very well sorted class. The Inclusive graphic Skewness, $(S k 1)$, ranging has an average $0.05 \Phi$, and the modal class located in the nearly symmetrical Skewed (67\%) whereas $29 \%$ located in the Fine Skewed class and 4\% located in the coarse skewed class.

Grain size analysis and screening process can be considered a physical dressing tool in the concentration of the economic heavy minerals in a defined size grade, (Barakat, 2004). The average percentage of grain size distribution of sand fractions and total heavy fractions along six profiles parallel to the shoreline are shown in Table (7).

The modal class of sand fractions is located in fine sand size with average value $71.31 \%$, whereas the modal class of total heavy fractions is located in very fine sand size with an average value $89.38 \%$.

\section{IV.3. Mineralogical investigations}

The average percentages of Bromoform (H.B.) and Clerici's solution (H.C.) heavy fractions along 51 profiles nearly perpendicular to the shoreline are shown in Table (8) and graphically represented in Fig. (9).

Also, the average percentages of Bromoform and Clerici's solution heavy fractions along ten square kilometers arranged from west to east parallel to the shoreline as well as the western and eastern halves of the southern sector of study area are shown in Table (9). 
Table (6): Distribution of calculated grain size parameters of sand fractions among different classes.

\begin{tabular}{|c|c|c|c|c|c|}
\hline \multicolumn{2}{|c|}{$\begin{array}{c}\text { Mean size } \\
\text { (Mz) }\end{array}$} & \multicolumn{2}{|c|}{$\begin{array}{l}\text { Sorting } \\
(\sigma 1)\end{array}$} & \multicolumn{2}{|c|}{$\begin{array}{l}\text { Skewness } \\
\text { (Sk1) }\end{array}$} \\
\hline class & $\%$ & class & $\%$ & Class & $\%$ \\
\hline 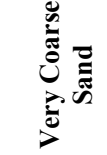 & -- & 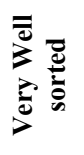 & 2 & 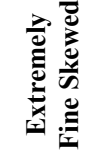 & ---- \\
\hline 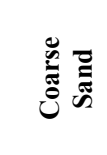 & --- & 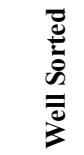 & 51 & 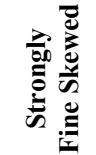 & --- \\
\hline 罭 & -- & $\geq 0$ & & $\stackrel{g}{:}$ & 29 \\
\hline 导 䔍 & 100 & $\bar{z}$ & 47 & 逽 & 67 \\
\hline 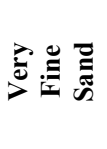 & -- & 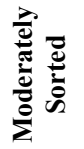 & - & 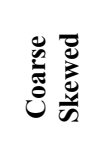 & 4 \\
\hline
\end{tabular}

Table (7): The average percentage of grain size distribution of sand fractions and total heavy fractions along six profiles parallel to the shoreline.

\begin{tabular}{|c|c|c|c|c|c|c|}
\hline \multirow[b]{2}{*}{ Profiles } & \multirow[b]{2}{*}{ Fraction } & \multicolumn{5}{|c|}{ Grain size distribution, (\%) } \\
\hline & & $\begin{array}{l}-1000 \mu \\
+500 \mu\end{array}$ & $\begin{array}{l}-500 \mu \\
+250 \mu\end{array}$ & $\begin{array}{l}-250 \mu \\
+125 \mu\end{array}$ & $\begin{array}{l}-125 \mu \\
+63 \mu\end{array}$ & $-63 \mu$ \\
\hline \multirow{2}{*}{$\mathbf{A}$} & sand $F$. & 0.73 & 8.63 & 69.55 & 20.37 & 0.72 \\
\hline & T.H.F. & $\mathbf{0}$ & 0.05 & 9.49 & 87.39 & 3.07 \\
\hline \multirow{2}{*}{ B } & sand $F$. & 0.38 & 8.26 & 70.97 & 19.84 & 0.56 \\
\hline & T.H.F. & 0 & 0.08 & 9.53 & 87.00 & 3.40 \\
\hline \multirow{2}{*}{ C } & sand $F$. & 0.53 & 9.05 & 72.17 & 17.68 & 0.58 \\
\hline & T.H.F. & $\mathbf{0}$ & 0.15 & 6.76 & 89.98 & 3.10 \\
\hline \multirow{2}{*}{ D } & sand $F$. & 0.51 & 8.30 & 72.50 & 18.24 & 0.44 \\
\hline & T.H.F. & $\mathbf{0}$ & 0.23 & 6.63 & 90.38 & 2.76 \\
\hline \multirow{2}{*}{$\mathbf{E}$} & sand $F$. & 0.44 & 8.72 & 71.13 & 19.26 & 0.45 \\
\hline & T.H.F. & $\mathbf{0}$ & 0.28 & 3.95 & 91.61 & 4.17 \\
\hline \multirow{2}{*}{$\mathbf{F}$} & sand $F$. & 0.45 & 9.07 & 71.56 & 18.30 & 0.62 \\
\hline & T.H.F. & $\mathbf{0}$ & 0.39 & 5.80 & 89.95 & 3.86 \\
\hline \multirow{2}{*}{ Average } & sand $F$. & 0.51 & 8.67 & 71.31 & 18.95 & 0.56 \\
\hline & T.H.F. & $\mathbf{0}$ & 0.20 & 7.03 & 89.38 & 3.39 \\
\hline
\end{tabular}


Table (8): The average percentages of Bromoform (H.B.) and Clerici's solution (H.C.) heavy fractions along 51 profiles nearly perpendicular to the shoreline.

\begin{tabular}{|c|c|c|c|c|c|}
\hline $\begin{array}{l}\text { Prof. } \\
\text { no }\end{array}$ & $\begin{array}{c}\text { H.B. } \\
(\%)\end{array}$ & $\begin{array}{c}\text { H.C. } \\
(\%)\end{array}$ & $\begin{array}{l}\text { Prof. } \\
\text { No }\end{array}$ & $\begin{array}{c}\text { H.B. } \\
(\%)\end{array}$ & $\begin{array}{c}\text { H.C. } \\
(\%)\end{array}$ \\
\hline 1 & 15.57 & 4.32 & 27 & 16.59 & 3.07 \\
\hline 2 & 18.63 & 4.94 & 28 & 16.97 & 2.65 \\
\hline 3 & 15.38 & 2.87 & 29 & 16.40 & 2.48 \\
\hline 4 & 19.77 & 5.71 & 30 & 11.07 & 1.13 \\
\hline 5 & 18.79 & 4.97 & 31 & 10.31 & $\mathbf{0 . 8 9}$ \\
\hline 6 & 18.10 & 4.47 & 32 & 12.07 & 1.78 \\
\hline 7 & 23.02 & 6.55 & 33 & 9.34 & 1.10 \\
\hline 8 & 20.57 & 5.39 & 34 & 12.01 & 1.53 \\
\hline 9 & 20.60 & 5.45 & 35 & 11.36 & 1.60 \\
\hline 10 & 22.36 & 5.92 & 36 & 11.29 & 1.73 \\
\hline 11 & 21.13 & 5.20 & 37 & 9.96 & 1.46 \\
\hline 12 & 21.01 & 5.35 & 38 & 11.78 & 2.06 \\
\hline 13 & 20.51 & 5.04 & 39 & 8.76 & 1.81 \\
\hline 14 & 20.40 & 4.74 & 40 & 11.69 & 1.95 \\
\hline 15 & 22.14 & 5.27 & 41 & 17.01 & 4.16 \\
\hline 16 & 18.82 & 4.67 & 42 & 14.50 & 3.52 \\
\hline 17 & 18.78 & 4.98 & 43 & 14.08 & 3.14 \\
\hline 18 & 20.82 & 5.02 & 44 & 13.27 & 3.04 \\
\hline 19 & 19.64 & 4.47 & 45 & 15.13 & 3.20 \\
\hline 20 & 20.66 & 4.95 & 46 & 14.43 & 3.35 \\
\hline 21 & 18.97 & 4.24 & 47 & 15.02 & 3.43 \\
\hline 22 & 20.22 & 5.20 & 48 & 16.82 & 3.90 \\
\hline 23 & 18.50 & 3.92 & 49 & 17.74 & 4.69 \\
\hline 24 & 18.07 & 3.77 & 50 & 17.35 & 4.22 \\
\hline 25 & 17.78 & 3.50 & 51 & 18.07 & 4.49 \\
\hline 26 & 14.45 & 2.90 & Av. & 16.60 & 3.70 \\
\hline & & & & & \\
\hline
\end{tabular}

\section{IV.3.1 Magnetic fractionation.}

Before using the electromagnetic separator, magnetite grains (ferromagnetic mineral) must be removed from each heavy sub-fraction with a hand magnet or by the using of Frantz, Ferrofilter Magnetic Separator (permanent magnet). The magnetite free heavy sub-fractions were subjected to magnetic fractionation using the Frantz Isodynamic Separator modal, (L-1). The average values of magnetic sub-fractions along the six profiles parallel to the shoreline are shown in Table (10).

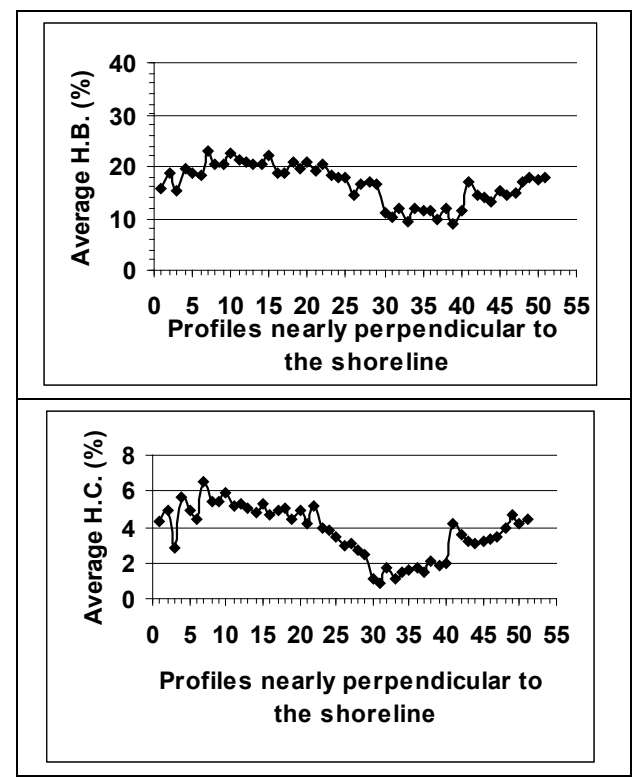

Fig. (9): Graphic representation of the average percentages of Bromoform (H.B.) and Clerici's solution (H.C.) heavy fractions along 51 profiles nearly perpendicular to the shoreline.

Each free magnetite sub-fraction was subjected to microscopic examination to identify and count the different heavy economic minerals. The microscopic investigation of the studied samples was carried out under the binocular stereomicroscope and transmitted polarizing light microscope.

The average values of magnetic subfractions along ten square kilometers and three zones arranged from west to east are shown in Table (11).

Table (9): The average percentages of Bromoform and Clerici's solution heavy fractions along ten square kilometers arranged from west to east parallel to the shoreline as well as the western and eastern halves of the southern sector of study area.

\begin{tabular}{|c|c|c|c|c|c|c|c|c|c|}
\hline & Area & & rage & $\mathrm{Br}(\mathrm{wt}$ & & & ige $F$ & I ( w & (o) \\
\hline \multirow{8}{*}{ West } & $1^{\text {st }}$ & 17.71 & 19.34 & \multirow{5}{*}{19.39} & \multirow{10}{*}{16.60} & 4.55 & $\begin{array}{l}5.03 \\
\end{array}$ & \multirow{5}{*}{4.75} & \multirow{10}{*}{3.70} \\
\hline & $2^{\text {nd }}$ & 20.96 & & & & 5.50 & & & \\
\hline & $3^{\text {rd }}$ & 20.67 & 20.14 & & & 5.04 & 4.88 & & \\
\hline & $4^{\text {th }}$ & 19.61 & & & & 4.72 & & & \\
\hline & $5^{\text {th }}$ & 18.00 & 16.15 & & & 3.92 & 3.05 & & \\
\hline & $6^{\text {th }}$ & 14.30 & & \multirow{5}{*}{13.68} & & 2.18 & & \multirow{5}{*}{2.64} & \\
\hline & $7^{\text {th }}$ & 11.06 & 11.41 & & & 1.44 & 1.82 & & \\
\hline & $8^{\text {th }}$ & 11.75 & & & & 2.19 & & & \\
\hline \multirow{2}{*}{ East } & $9^{\text {th }}$ & 14.74 & \multirow[b]{2}{*}{15.66} & & & 3.40 & \multirow[b]{2}{*}{3.71} & & \\
\hline & $10^{\text {th }}$ & 16.57 & & & & 4.01 & & & \\
\hline
\end{tabular}


Table (10): The average values of magnetic sub-fractions along the six profiles parallel to the shoreline.

\begin{tabular}{|c|c|c|c|c|c|c|}
\hline Profile & $\begin{array}{c}\text { Magn } \\
\text { (Wt \%) }\end{array}$ & $\begin{array}{c}\text { Mag. 0.2 } \\
\text { (Wt \%) }\end{array}$ & $\begin{array}{c}\text { Mag. 0.5 } \\
\text { (Wt \%) }\end{array}$ & $\begin{array}{c}\text { Mag. 1.0 } \\
\text { (Wt \%) }\end{array}$ & $\begin{array}{c}\text { Mag. 1.5 } \\
\text { (Wt \%) }\end{array}$ & N.Mag. 1.5 \\
\hline A & 1.699 & 2.711 & 0.558 & 0.042 & 0.028 & 0.261 \\
\hline B & 1.186 & 2.021 & 0.378 & 0.032 & 0.021 & 0.165 \\
\hline C & 1.095 & 1.791 & 0.282 & 0.025 & 0.019 & 0.131 \\
\hline D & 1.018 & 1.877 & 0.311 & 0.014 & 0.009 & 0.124 \\
\hline E & 1.087 & 1.924 & 0.401 & 0.020 & 0.017 & 0.135 \\
\hline F & 0.874 & 1.660 & 0.304 & 0.017 & 0.010 & 0.131 \\
\hline Av. & 1.160 & 1.997 & 0.372 & 0.025 & 0.017 & 0.158 \\
\hline
\end{tabular}

The average values of economic minerals along 51 profiles nearly perpendicular to the shoreline were calculated and tabulated in Table (12) and graphically represented in Fig. (10).

The average values of economic minerals content along ten square kilometers and three zones arranged from west to east are shown in Table (13).

Minimum, maximum and average values of economic minerals content relative to raw sand were calculated and tabulated in Table (14).

Table (11): The average values of magnetic sub-fractions along ten kilometers and three zones arranged from west to east in the study area.

\begin{tabular}{|c|c|c|c|c|c|c|c|}
\hline Area & Zones & Mag & tite, $\%$ & Mag. & $2, \%$ & & $.5, \%$ \\
\hline $1^{\text {st }}$ & \multirow{4}{*}{ Western } & 1.26 & \multirow{4}{*}{1.561} & 2.53 & \multirow{4}{*}{2.645} & 0.48 & \multirow{4}{*}{0.489} \\
\hline $2^{\text {nd }}$ & & 1.69 & & 2.99 & & 0.55 & \\
\hline $3^{\text {rd }}$ & & 1.70 & & 2.61 & & 0.48 & \\
\hline $4^{\text {th }}$ & & 1.59 & & 2.45 & & 0.44 & \\
\hline $5^{\text {th }}$ & \multirow{3}{*}{ Middle } & 1.31 & \multirow{3}{*}{0.830} & 2.04 & \multirow{3}{*}{1.307} & 0.38 & \multirow{3}{*}{0.256} \\
\hline $6^{\text {th }}$ & & 0.72 & & 1.14 & & 0.23 & \\
\hline $7^{\text {th }}$ & & 0.47 & & 0.74 & & 0.16 & \\
\hline $8^{\text {th }}$ & \multirow{3}{*}{ Eastern } & 0.64 & \multirow{3}{*}{0.936} & 1.20 & \multirow{3}{*}{1.752} & 0.23 & \multirow{3}{*}{0.323} \\
\hline $9^{\text {th }}$ & & 1.01 & & 1.85 & & 0.34 & \\
\hline $10^{\text {th }}$ & & 1.15 & & 2.21 & & 0.40 & \\
\hline Area & Zones & \multicolumn{2}{|c|}{ Mag.1.0, \% } & \multicolumn{2}{|c|}{ Mag.1.5, \% } & \multicolumn{2}{|c|}{ N.Mag. $1.5, \%$} \\
\hline $1^{\text {st }}$ & \multirow{4}{*}{ Western } & 0.03 & \multirow{4}{*}{0.030} & 0.023 & \multirow{4}{*}{0.021} & 0.22 & \multirow{4}{*}{0.206} \\
\hline $2^{\text {nd }}$ & & 0.03 & & 0.021 & & 0.21 & \\
\hline $3^{\text {rd }}$ & & 0.03 & & 0.021 & & 0.20 & \\
\hline $4^{\text {th }}$ & & 0.03 & & 0.021 & & 0.19 & \\
\hline $5^{\text {th }}$ & \multirow{3}{*}{ Middle } & 0.03 & \multirow{3}{*}{0.017} & 0.019 & \multirow{3}{*}{0.013} & 0.15 & \multirow{3}{*}{0.092} \\
\hline $6^{\text {th }}$ & & 0.02 & & 0.012 & & 0.08 & \\
\hline $7^{\text {th }}$ & & 0.01 & & 0.008 & & 0.05 & \\
\hline $8^{\text {th }}$ & \multirow{3}{*}{ Eastern } & 0.01 & \multirow{3}{*}{0.023} & 0.009 & \multirow{3}{*}{0.014} & 0.10 & \multirow{3}{*}{0.155} \\
\hline $9^{\text {th }}$ & & 0.02 & & 0.015 & & 0.16 & \\
\hline $10^{\text {th }}$ & & 0.03 & & 0.019 & & 0.20 & \\
\hline
\end{tabular}

Table (12): The average values of economic minerals content along 51 profiles nearly perpendicular to the shoreline in the study area.

\begin{tabular}{|c|c|c|c|c|c|c|c|}
\hline $\begin{array}{c}\text { Profile } \\
\text { No }\end{array}$ & $\begin{array}{c}\text { Magt. } \\
\%\end{array}$ & $\underset{\%}{\text { IIm. }}$ & $\begin{array}{c}\text { Gar. } \\
\%\end{array}$ & $\begin{array}{c}\text { Leu. } \\
\%\end{array}$ & $\underset{\%}{\text { Zir. }}$ & $\begin{array}{c}\text { Rut. } \\
\%\end{array}$ & $\begin{array}{c}\text { Mon. } \\
\%\end{array}$ \\
\hline 1 & 1.20 & 2.53 & 0.16 & 0.11 & 0.16 & 0.053 & 0.006 \\
\hline 2 & 1.24 & 2.99 & 0.21 & 0.13 & 0.21 & 0.070 & 0.010 \\
\hline 3 & 0.79 & 1.69 & 0.11 & 0.07 & 0.10 & 0.034 & 0.006 \\
\hline 4 & 1.68 & 3.25 & 0.22 & 0.15 & 0.23 & 0.078 & 0.010 \\
\hline 5 & 1.45 & 2.81 & 0.23 & 0.12 & 0.20 & 0.065 & 0.009 \\
\hline 6 & 1.22 & 2.59 & 0.19 & 0.11 & 0.18 & 0.060 & 0.007 \\
\hline 7 & 2.00 & 3.76 & 0.23 & 0.16 & 0.19 & 0.062 & 0.010 \\
\hline 8 & 1.48 & 3.17 & 0.26 & 0.12 & 0.19 & 0.065 & 0.009 \\
\hline 9 & 1.77 & 3.10 & 0.15 & 0.13 & 0.16 & $\mathbf{0 . 0 5 3}$ & 0.007 \\
\hline 10 & 1.97 & 3.26 & 0.20 & 0.14 & 0.18 & 0.059 & 0.008 \\
\hline 11 & 1.72 & 2.85 & 0.18 & 0.12 & 0.16 & 0.054 & 0.007 \\
\hline 12 & 1.76 & 2.94 & 0.18 & 0.13 & 0.20 & 0.066 & 0.009 \\
\hline 13 & 1.69 & 2.78 & 0.14 & 0.12 & 0.14 & $\mathbf{0 . 0 4 8}$ & 0.007 \\
\hline
\end{tabular}




\begin{tabular}{|c|c|c|c|c|c|c|c|}
\hline 14 & 1.59 & 2.52 & 0.23 & 0.12 & 0.15 & 0.051 & 0.009 \\
\hline 15 & 1.83 & 2.78 & 0.23 & 0.13 & 0.17 & 0.056 & 0.008 \\
\hline 16 & 1.59 & 2.53 & 0.13 & 0.11 & 0.16 & 0.054 & 0.007 \\
\hline 17 & 1.76 & 2.61 & 0.18 & 0.12 & $\mathbf{0 . 1 7}$ & 0.058 & 0.007 \\
\hline 18 & 1.59 & 2.81 & 0.19 & 0.12 & 0.17 & 0.057 & 0.008 \\
\hline 19 & 1.49 & 2.38 & 0.21 & 0.11 & 0.15 & 0.051 & 0.007 \\
\hline 20 & 1.69 & 2.60 & 0.23 & 0.12 & 0.16 & 0.054 & 0.008 \\
\hline 21 & 1.43 & 2.25 & 0.21 & 0.10 & 0.14 & 0.046 & 0.006 \\
\hline 22 & 1.66 & 2.84 & 0.24 & 0.13 & 0.18 & 0.059 & 0.009 \\
\hline 23 & 1.32 & 2.12 & 0.15 & 0.09 & 0.13 & 0.042 & 0.006 \\
\hline 24 & 1.24 & 2.04 & 0.16 & 0.09 & 0.12 & 0.040 & 0.007 \\
\hline 25 & 1.26 & 1.81 & 0.13 & 0.08 & 0.11 & 0.037 & 0.005 \\
\hline 26 & 0.92 & 1.60 & 0.12 & 0.07 & 0.09 & 0.028 & 0.005 \\
\hline 27 & 1.02 & 1.64 & 0.12 & 0.08 & 0.11 & 0.035 & 0.006 \\
\hline 28 & 0.93 & 1.42 & 0.08 & 0.06 & 0.07 & 0.022 & 0.004 \\
\hline 29 & $\mathbf{0 . 8 3}$ & 1.33 & 0.09 & 0.06 & 0.08 & $\mathbf{0 . 0 2 7}$ & 0.005 \\
\hline 30 & 0.31 & $\begin{array}{l}0.63 \\
\end{array}$ & 0.05 & 0.03 & 0.04 & 0.012 & 0.002 \\
\hline 31 & 0.29 & 0.44 & 0.04 & 0.02 & 0.02 & 0.008 & 0.002 \\
\hline 32 & 0.47 & 1.02 & 0.06 & 0.05 & 0.07 & 0.022 & 0.004 \\
\hline 33 & 0.37 & 0.56 & 0.05 & \begin{tabular}{|c|}
0.03 \\
\end{tabular} & 0.04 & 0.012 & 0.002 \\
\hline 34 & 0.55 & 0.77 & 0.06 & $\begin{array}{l}0.04 \\
\end{array}$ & 0.04 & 0.014 & 0.002 \\
\hline 35 & 0.56 & 0.82 & 0.05 & 0.04 & 0.05 & 0.017 & 0.003 \\
\hline 36 & 0.56 & 0.92 & $\mathbf{0 . 0 7}$ & 0.04 & 0.05 & 0.017 & 0.003 \\
\hline 37 & 0.44 & 0.81 & 0.06 & 0.04 & 0.04 & 0.012 & 0.003 \\
\hline 38 & 0.63 & 1.13 & 0.08 & $\begin{array}{l}0.05 \\
\end{array}$ & $\mathbf{0 . 0 7}$ & 0.024 & 0.003 \\
\hline 39 & 0.46 & 1.05 & 0.07 & 0.04 & 0.08 & 0.027 & 0.003 \\
\hline 40 & 0.45 & 1.16 & 0.09 & 0.05 & 0.08 & 0.027 & 0.005 \\
\hline 41 & 1.32 & 2.30 & 0.16 & 0.09 & $\mathbf{0 . 1 7}$ & 0.055 & 0.004 \\
\hline 42 & 0.99 & 2.01 & 0.16 & 0.08 & 0.15 & 0.050 & 0.006 \\
\hline 43 & 0.89 & 1.81 & 0.11 & 0.09 & 0.10 & $\mathbf{0 . 0 3 5}$ & 0.007 \\
\hline 44 & 0.86 & 1.75 & 0.13 & 0.07 & 0.12 & 0.041 & 0.005 \\
\hline 45 & 0.94 & 1.81 & 0.14 & 0.08 & 0.11 & 0.038 & 0.005 \\
\hline 46 & 1.05 & 1.83 & 0.13 & 0.08 & 0.14 & 0.046 & 0.007 \\
\hline 47 & 1.03 & 1.93 & 0.13 & 0.09 & 0.13 & 0.043 & 0.007 \\
\hline 48 & 1.03 & 2.31 & 0.15 & 0.09 & 0.16 & 0.054 & 0.007 \\
\hline 49 & 1.43 & 2.59 & 0.22 & 0.12 & 0.19 & 0.065 & 0.009 \\
\hline 50 & 1.21 & 2.41 & 0.18 & 0.10 & 0.18 & 0.059 & 0.007 \\
\hline 51 & 1.17 & 2.60 & 0.23 & 0.12 & 0.20 & 0.067 & 0.008 \\
\hline Average & 1.15 & 2.07 & 0.15 & 0.09 & 0.13 & 0.044 & 0.006 \\
\hline
\end{tabular}

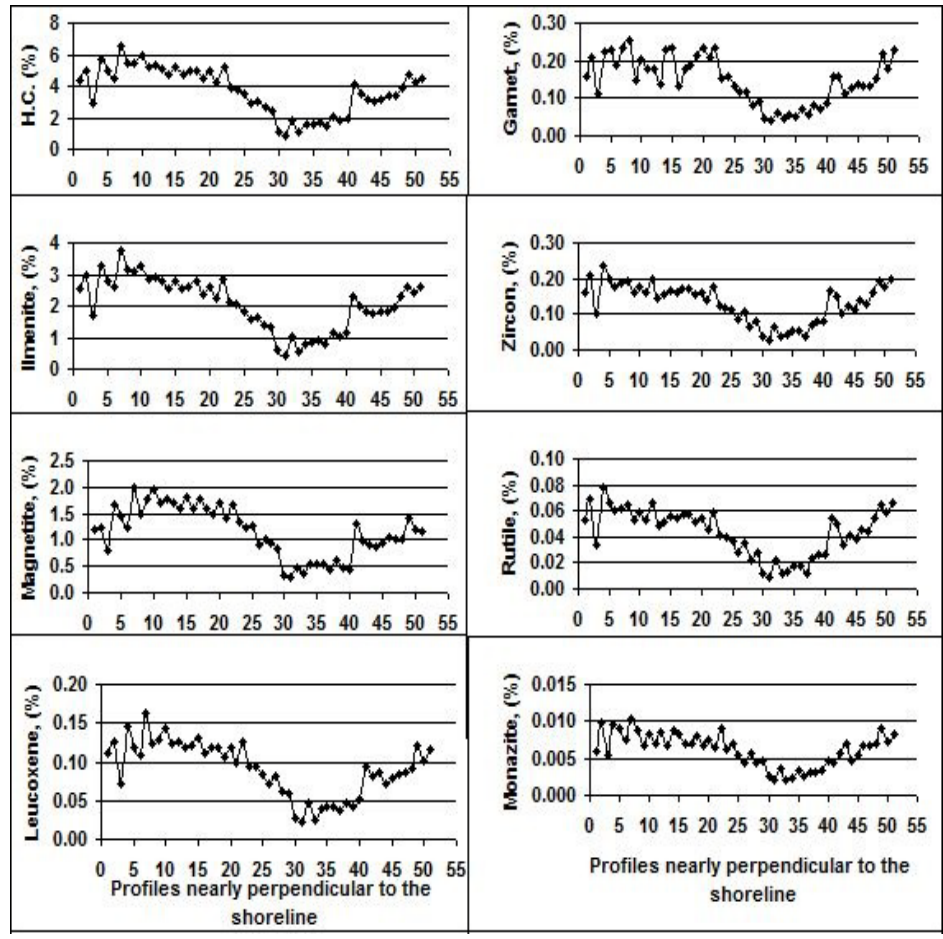

Fig. (10): Graphic representation showing the average values of economic minerals content along 51 profiles nearly perpendicular to the shoreline in the study area. 
Table (13): The average values of economic heavy minerals content along ten square kilometers and three zones arranged from west to east in the study area.

\begin{tabular}{|c|c|c|c|c|c|c|c|c|c|}
\hline Area & Zones & \multicolumn{2}{|c|}{ HCl\% } & \multicolumn{2}{|c|}{ Magnetite, \% } & \multicolumn{2}{|c|}{ Ilmenite, \% } & \multicolumn{2}{|c|}{ Garnet, \% } \\
\hline $1^{\text {st }}$ & \multirow{4}{*}{ Western } & 4.55 & \multirow{4}{*}{4.95} & 1.26 & \multirow{4}{*}{1.56} & 2.64 & \multirow{4}{*}{2.76} & 0.19 & \multirow{4}{*}{0.19} \\
\hline $2^{\text {nd }}$ & & 5.50 & & 1.69 & & 3.12 & & 0.20 & \\
\hline $3^{\text {rd }}$ & & 5.04 & & 1.70 & & 2.73 & & 0.18 & \\
\hline $4^{\text {th }}$ & & 4.72 & & 1.59 & & 2.53 & & 0.19 & \\
\hline $5^{\text {th }}$ & \multirow{3}{*}{ Middle } & 3.92 & \multirow{3}{*}{2.51} & 1.31 & \multirow{3}{*}{0.83} & 2.11 & \multirow{3}{*}{1.35} & 0.17 & \multirow{3}{*}{0.10} \\
\hline $6^{\text {th }}$ & & 2.18 & & 0.72 & & 1.18 & & 0.08 & \\
\hline $7^{\text {th }}$ & & 1.44 & & 0.47 & & 0.76 & & 0.05 & \\
\hline $8^{\text {th }}$ & \multirow{3}{*}{ Eastern } & 2.19 & \multirow{3}{*}{3.20} & 0.64 & \multirow{3}{*}{0.94} & 1.23 & \multirow{3}{*}{1.81} & 0.09 & \multirow{3}{*}{0.13} \\
\hline $9^{\text {th }}$ & & 3.40 & & 1.01 & & 1.92 & & 0.14 & \\
\hline $10^{\text {th }}$ & & 4.01 & & 1.15 & & 2.28 & & 0.17 & \\
\hline \multicolumn{2}{|c|}{ Average } & \multicolumn{2}{|c|}{3.70} & \multicolumn{2}{|c|}{1.15} & \multicolumn{2}{|c|}{2.07} & \multicolumn{2}{|c|}{0.15} \\
\hline Area & Zones & \multicolumn{2}{|c|}{ Leucoxene, \% } & \multicolumn{2}{|c|}{ Zircon, \% } & \multicolumn{2}{|c|}{ Rutile,\% } & \multicolumn{2}{|c|}{ Monazite, \% } \\
\hline $1^{\text {st }}$ & \multirow{4}{*}{ Western } & 0.114 & \multirow{4}{*}{0.120} & 0.180 & \multirow{4}{*}{0.170} & 0.060 & \multirow{4}{*}{0.057} & 0.0079 & \\
\hline $2^{\text {nd }}$ & & 0.131 & & 0.177 & & 0.059 & & 0.0080 & 00077 \\
\hline $3^{\text {rd }}$ & & 0.122 & & 0.165 & & 0.055 & & 0.0077 & $0.00 / 1 /$ \\
\hline $4^{\text {th }}$ & & 0.112 & & 0.160 & & 0.053 & & 0.0071 & \\
\hline $5^{\text {th }}$ & & 0.095 & & 0.126 & & 0.042 & & 0.0064 & \\
\hline $6^{\text {th }}$ & Middle & 0.054 & 0.062 & 0.067 & 0.079 & 0.022 & 0.026 & 0.0040 & 0.0044 \\
\hline $7^{\text {th }}$ & & 0.036 & & 0.045 & & 0.015 & & 0.0027 & \\
\hline $8^{\text {th }}$ & & 0.053 & & 0.081 & & 0.027 & & 0.0035 & \\
\hline $9^{\text {th }}$ & Eastern & 0.083 & 0.078 & 0.132 & 0.127 & 0.044 & 0.042 & 0.0057 & 0.0056 \\
\hline $10^{\text {th }}$ & & 0.100 & & 0.167 & & 0.056 & & 0.0075 & \\
\hline & & & & & & & & & \\
\hline
\end{tabular}

Table (14): Minimum, maximum and average values of economic heavy minerals.

\begin{tabular}{|l|c|c|c|}
\hline Mineral & Minimum & Maximum & Average \\
\hline Magnetite & $\mathbf{0 . 0 6 0 8}$ & 4.3400 & $\mathbf{1 . 1 5 0 0}$ \\
\hline Ilmenite & $\mathbf{0 . 3 3 0 6}$ & 7.3937 & $\mathbf{2 . 0 7 1 4}$ \\
\hline Garnet & $\mathbf{0 . 0 1 4 7}$ & $\mathbf{0 . 7 6 1 1}$ & $\mathbf{0 . 1 4 8 1}$ \\
\hline Leucoxene & $\mathbf{0 . 0 1 1 0}$ & $\mathbf{0 . 3 9 1 7}$ & $\mathbf{0 . 0 9 1 0}$ \\
\hline Zircon & $\mathbf{0 . 0 0 2 0}$ & $\mathbf{0 . 6 0 8 2}$ & $\mathbf{0 . 1 3 1 2}$ \\
\hline Rutile & $\mathbf{0 . 0 0 1 0}$ & $\mathbf{0 . 2 0 2 7}$ & $\mathbf{0 . 0 4 3 7}$ \\
\hline Monazite & $\mathbf{0 . 0 0 0 2}$ & $\mathbf{0 . 0 2 2 4}$ & $\mathbf{0 . 0 0 6 1}$ \\
\hline
\end{tabular}

\section{Evaluation of study area.}

The study coastal plain area is more or less plained surface so that, the volume of raw sand is roughly calculated as length $(\mathrm{m}) \mathrm{x}$ width $(\mathrm{m})$ $\mathrm{x}$ depth $(\mathrm{m})$ in $\mathrm{m}^{3}$. The tonnage of the raw sand was calculated by multiplying the volume $\left(\mathrm{m}^{3}\right)$ by the calculated average apparent density of the raw sand, the results are shown in Table (15).

The tonnage of total economic minerals was calculated by multiplying the tonnage of the raw sands by the calculated average weight percentage of total economic mineral, Table (16).

The tonnage of each individual economic mineral was calculated by multiplying the tonnage of the raw sand of the studied area by the calculated weight percentage of each economic mineral, Table (17).
Table (15): Volume and tonnage of raw sand of studied area.

\begin{tabular}{|c|c|c|}
\hline $\begin{array}{c}\text { Volume }\left(\mathrm{m}^{3}\right) \\
\text { of raw sand }\end{array}$ & $\begin{array}{c}\text { Average apparent } \\
\text { Density Of raw } \\
\text { sand }\left(\text { ton } / \mathbf{m}^{3}\right)\end{array}$ & $\begin{array}{c}\text { Tonnage Of } \\
\text { raw sand } \\
\text { (tons) }\end{array}$ \\
\hline $\begin{array}{c}10000 \times 1000 \\
\times 1=\end{array}$ \\
\begin{tabular}{c}
$\mathbf{1 0 , 0 0 0 0 0 0}$ \\
\hline
\end{tabular}
\end{tabular}

Table (16): Reserve of total economic minerals in the studied area.

\begin{tabular}{|c|c|c|}
\hline $\begin{array}{c}\text { Tonnage Of } \\
\text { raw } \\
\text { sand,(tons) }\end{array}$ & $\begin{array}{c}\text { Av. } \\
\text { Economic } \\
\text { Minerals } \\
\text { Content, } \\
\text { wt. } \%\end{array}$ & $\begin{array}{c}\text { Reserve of total } \\
\text { economic minerals, } \\
\text { (tons) }\end{array}$ \\
\hline 15,900000 & 3.64 & 578,760 \\
\hline
\end{tabular}

Table (17): The average content (Av. cont., Wt. $\%$ ) and reserve tonnage for each economic mineral in the study area.

\begin{tabular}{|c|c|c|}
\hline $\begin{array}{c}\text { Economic } \\
\text { mineral }\end{array}$ & $\begin{array}{c}\text { Av .cont. } \\
\text { wt. } \%\end{array}$ & $\begin{array}{c}\text { Reserve } \\
\text { (tons) }\end{array}$ \\
\hline Magnetite & 1.15 & 182,850 \\
\hline Ilmenite & 2.07 & $\mathbf{3 2 9 , 1 3 0}$ \\
\hline Garnet & $\mathbf{0 . 1 5}$ & $\mathbf{2 3 , 8 5 0}$ \\
\hline Leucoxene & $\mathbf{0 . 0 9}$ & $\mathbf{1 4 , 3 1 0}$ \\
\hline Zircon & $\mathbf{0 . 1 3}$ & $\mathbf{2 0 , 6 7 0}$ \\
\hline Rutile & $\mathbf{0 . 0 4 4}$ & $\mathbf{6 , 9 9 6}$ \\
\hline Monazite & $\mathbf{0 . 0 0 6}$ & 954 \\
\hline Total & $\mathbf{3 . 6 4}$ & $\mathbf{5 7 8 , 7 6 0}$ \\
\hline
\end{tabular}




\section{RADIOMETRIC SURVEY}

The average values of radiometric measurements along various square kilometers parallel to the shoreline from the first kilometer in the west to the tenth kilometer in the east which divided into three zones are shown in the Table (18) and graphically represented in Fig. (11).
From Fig. (11), it is clearly observed that the area can be divided into three zones according to their contents of total counts (CPS), eTh (ppm) and eU (ppm). The western zone characterized by relatively high radiometric contents, then the eastern zone and the finally the middle zone which have low radiometric contents.

Table (18): Distribution of the radioelements along various square kilometers parallel to the shoreline arranged from west to east and the corresponding three zones.

\begin{tabular}{|c|c|c|c|c|c|c|c|c|c|}
\hline \multirow{3}{*}{$\begin{array}{c}\text { Area } \\
1^{\text {st }} \\
2^{\text {nd }} \\
\end{array}$} & Zone & Tot: & $\begin{array}{l}\text { count } \\
\text { s) }\end{array}$ & & $\begin{array}{l}\text { Th } \\
\text { m) }\end{array}$ & & & & K \\
\hline & \multirow{4}{*}{$\begin{array}{l}\overrightarrow{5} \\
\overrightarrow{0}\end{array}$} & 25.9 & \multirow{4}{*}{20.45} & 33.1 & \multirow{4}{*}{24.95} & 7.1 & \multirow{4}{*}{5.75} & 0.5 & \multirow{4}{*}{0.50} \\
\hline & & 24.1 & & 30.4 & & 6.3 & & 0.5 & \\
\hline $3^{\text {rd }}$ & & 18.8 & & 22.1 & & 5.6 & & 0.5 & \\
\hline $4^{\text {th }}$ & & 13.0 & & 14.2 & & 4.0 & & 0.5 & \\
\hline $5^{\text {th }}$ & \multirow{3}{*}{$\begin{array}{l}\stackrel{0}{\bar{z}} \\
\stackrel{0}{\Sigma}\end{array}$} & 8.4 & \multirow{3}{*}{6.10} & 8.6 & \multirow{3}{*}{5.03} & 2.6 & \multirow{3}{*}{1.80} & 0.4 & \multirow{3}{*}{0.53} \\
\hline $6^{\text {th }}$ & & 5.3 & & 4.0 & & 1.7 & & 0.5 & \\
\hline $7^{\text {th }}$ & & 4.6 & & 2.5 & & 1.1 & & 0.7 & \\
\hline $8^{\text {th }}$ & \multirow{3}{*}{ 芶 } & 7.2 & \multirow{3}{*}{8.37} & 6.2 & \multirow{3}{*}{7.70} & 1.9 & \multirow{3}{*}{2.43} & 0.7 & \multirow{3}{*}{0.60} \\
\hline $9^{\text {th }}$ & & 9.2 & & 8.7 & & 2.7 & & 0.6 & \\
\hline $10^{\text {th }}$ & & 8.7 & & 8.1 & & 2.7 & & 0.6 & \\
\hline
\end{tabular}

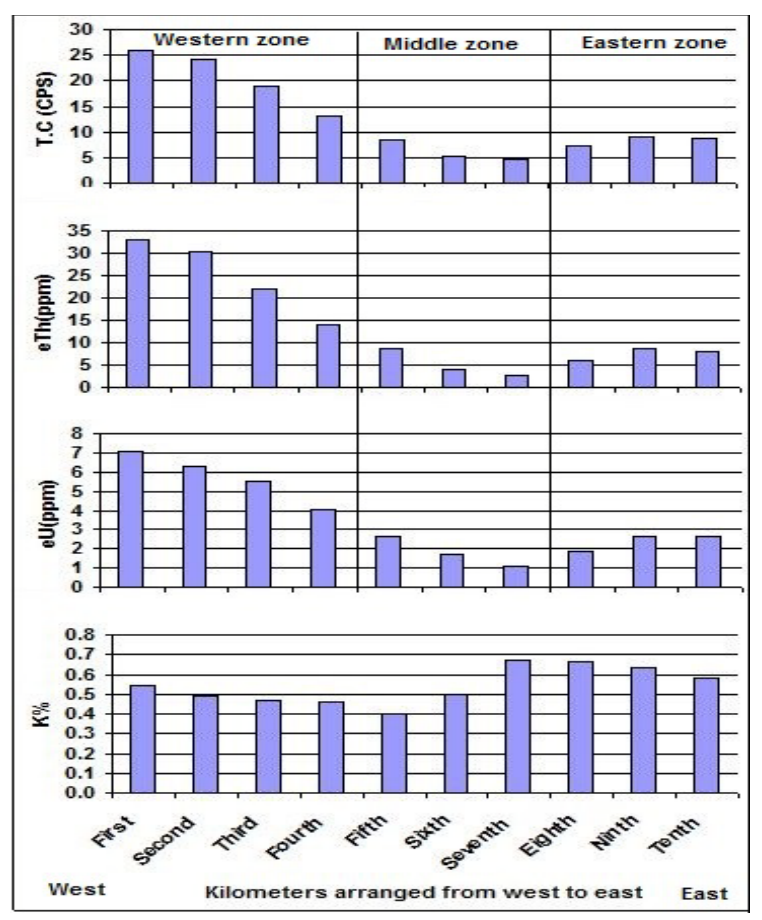

Fig. (11): Histograms showing the distribution of the radioelements along various kilometers parallel to the shoreline arranged from west to east and the corresponding three zones.

Specific activity (activity per unit mass) is the number of atomic decays per unit time per unit mass. It is used to describe the radionuclide contents of rocks and building materials. It is expressed in Becquerel per kilogram, $(\mathrm{Bq} / \mathrm{kg})$. The values of eU and $\mathrm{eTh}$ in (ppm) as well as $\mathrm{K}$ in (percent) were converted to activity concentrations, $(\mathrm{Bq} / \mathrm{kg})$, using the conversion factors given by the International Atomic Energy Agency (1979).The activity concentration of a sample containing $1(\mathrm{ppm})$ by weight of ${ }^{238} \mathrm{U}$ is $12.35(\mathrm{~Bq} / \mathrm{kg}), 1(\mathrm{ppm})$ of ${ }^{232} \mathrm{Th}$ is $4.06(\mathrm{~Bq} / \mathrm{kg})$ and $1(\%)$ of ${ }^{40} \mathrm{~K}$ is $313(\mathrm{~Bq} / \mathrm{kg})$. 
The specific activity concentrations of natural radioelements along various square kilometers which arranged from west to east parallel to the shoreline and the corresponding three zones are shown in Table (19) and graphically represented in Fig. (12).

Table (19): The specific activity $(\mathrm{Bq} / \mathrm{Kg})$ of natural radioelements along various square kilometers which arranged from west to east parallel to the shoreline and the corresponding three zones.

\begin{tabular}{|c|c|c|c|c|c|c|c|c|c|}
\hline Area & Zone & \multicolumn{2}{|c|}{$\begin{array}{c}\mathrm{K} \\
\text { activity } \\
\text { (Bq/Kg) }\end{array}$} & \multicolumn{2}{|c|}{$\begin{array}{c}\mathrm{U}, \\
\text { activity } \\
\text { (Bq/Kg) }\end{array}$} & \multicolumn{2}{|c|}{$\begin{array}{c}\text { Th, } \\
\text { activity } \\
\text { (Bq/Kg) }\end{array}$} & \multicolumn{2}{|c|}{$\begin{array}{c}\text { Total, } \\
\text { activity } \\
\text { (Bq/Kg) } \\
\end{array}$} \\
\hline $1^{\text {st }}$ & \multirow{4}{*}{$\sum_{\overrightarrow{0}}^{\vec{s}}$} & 170.41 & \multirow{4}{*}{153.24} & 87.38 & \multirow{4}{*}{70.87} & 134.24 & \multirow{4}{*}{101.22} & 392.03 & \multirow{4}{*}{325.325} \\
\hline $2^{\text {nd }}$ & & 153.02 & & 77.84 & & 123.59 & & 354.45 & \\
\hline $3^{\text {rd }}$ & & 146.07 & & 68.58 & & 89.59 & & 304.23 & \\
\hline $4^{\text {th }}$ & & 143.46 & & 49.67 & & 57.46 & & 250.59 & \\
\hline $5^{\text {th }}$ & \multirow{3}{*}{$\stackrel{\frac{0}{\bar{z}}}{\frac{2}{2}}$} & 126.07 & \multirow{3}{*}{164.04} & 32.52 & \multirow{3}{*}{22.32} & 35.11 & \multirow{3}{*}{20.61} & 193.70 & \multirow{3}{*}{206.96} \\
\hline $6^{\text {th }}$ & & 155.63 & & 21.30 & & 16.42 & & 193.35 & \\
\hline $7^{\text {th }}$ & & 210.41 & & 13.14 & & 10.30 & & 233.84 & \\
\hline $8^{\text {th }}$ & \multirow{3}{*}{ 离 } & 208.67 & \multirow{3}{*}{196.49} & 23.19 & \multirow{3}{*}{29.70} & 24.99 & \multirow{3}{*}{31.10} & 256.85 & \multirow{3}{*}{257.30} \\
\hline $9^{\text {th }}$ & & 199.10 & & 32.97 & & 35.30 & & 267.37 & \\
\hline $10^{\text {th }}$ & & 181.71 & & 32.93 & & 33.02 & & 247.67 & \\
\hline \multicolumn{2}{|c|}{ Average } & \multicolumn{2}{|c|}{170.51} & \multicolumn{2}{|c|}{ 43.89 } & \multicolumn{2}{|c|}{56.22} & \multicolumn{2}{|c|}{270.62} \\
\hline
\end{tabular}

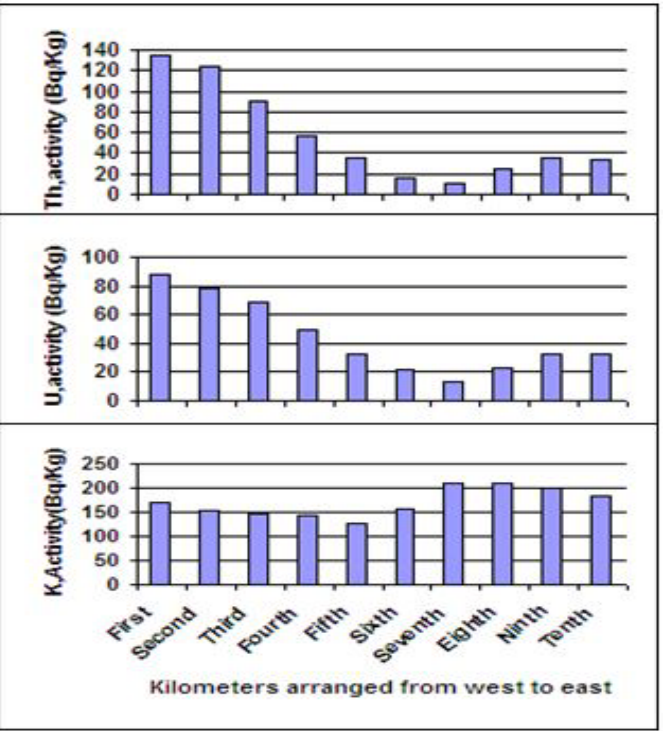

Fig. (12): Histograms showing the specific activity $(\mathrm{Bq} / \mathrm{Kg})$ of natural radioelements along various square kilometers which arranged from west to east parallel to the shoreline and the corresponding three zones.

From Table (19) and Fig. (12), we can conclude that the specific activity concentrations of natural radioelements $\left({ }^{232} \mathrm{Th}\right.$ $\left.\&{ }^{238} \mathrm{U}\right)$ of the western zone has a relatively high activity concentration, followed by the eastern zone then the the middle zone which has the lowest activity concentration. The activity concentration of the western zone is higher than the worldwide average of $40(\mathrm{~Bq} / \mathrm{kg})$ compared with the middle and eastern zones which have low values.

\section{V.1 Radioactive doses rate from sands}

The radiation dose is expressed in terms of energy received per unit weight and described in three ways: absorbed, equivalent, and effective. Radiation doses depend on, the intensity and energy of radiation, exposure time, the area exposed and the depth of energy deposition.

\section{V.1.1. Absorbed dose.}

The amount of energy deposited in a substance (e.g., human tissue), is called the absorbed dose. The absorbed dose is measured 
in a unit called the gray (Gy). A dose of one gray is equivalent to a unit of energy (joule) deposited in a kilogram of a substance $(1 \mathrm{~Gy}=1$ joule $/ \mathrm{kg}=100 \mathrm{rad}$ ).

The conversion factor used to calculate the absorbed dose rate is given as: Ab.Dose, $(\mathrm{nGy} / \mathrm{h})=0.429 \mathrm{U}+0.666 \mathrm{Th}+0.042 \mathrm{~K}$, where $\mathrm{U}$, Th and $\mathrm{K}$ are the specific activity concentration of $\left.\left({ }^{238} \mathrm{U}\right),{ }^{232} \mathrm{Th}\right)$ and $\left({ }^{40} \mathrm{~K}\right)$ in $(\mathrm{Bq} / \mathrm{kg})$, respectively, (United Nations Scientific Committee on the Effects of Atomic Radiation (UNSCEAR), 1988).

The total absorbed dose rate along various square kilometers which arranged from west to east parallel to the shoreline and the corresponding three zones are shown in Table (20).

Table (20): The total absorbed dose rate along various kilometers which arranged from west to east parallel to the shoreline and the corresponding three zones.

\begin{tabular}{|c|c|c|c|}
\hline Area & Zone & \multicolumn{2}{|c|}{$\begin{array}{c}\text { Total } \\
\text { Ab.Dose } \\
(\mathbf{n G y} / \mathbf{h})\end{array}$} \\
\hline $1^{\text {st }}$ & \multirow{4}{*}{ Western } & 134.05 & \multirow{4}{*}{104.25} \\
\hline $2^{\text {nd }}$ & & 122.13 & \\
\hline $3^{\text {rd }}$ & & 95.22 & \\
\hline $4^{\text {th }}$ & & 65.60 & \\
\hline $5^{\text {th }}$ & \multirow{3}{*}{ Middle } & 42.63 & \multirow{3}{*}{30.19} \\
\hline $6^{\text {th }}$ & & 26.61 & \\
\hline $7^{\text {th }}$ & & 21.33 & \\
\hline $8^{\text {th }}$ & \multirow{3}{*}{ Eastern } & 35.36 & \multirow{3}{*}{41.71} \\
\hline $9^{\text {th }}$ & & 46.01 & \\
\hline $10^{\text {th }}$ & & 43.75 & \\
\hline Av. & & 63.37 & \\
\hline
\end{tabular}

From Table (28), and according to the total absorbed dose rate of natural radioelements $\left({ }^{40} \mathrm{~K},{ }^{238} \mathrm{U}\right.$ and $\left.{ }^{232} \mathrm{Th}\right)$, the western zone has a relatively high total absorbed dose rate (104.25, $\mathrm{nGy} / \mathrm{h})$, followed by the eastern zone (41.71, $\mathrm{nGy} / \mathrm{h}$ ) and then the middle zone which has the lowest total absorbed dose rate $(30.19, \mathrm{nGy} / \mathrm{h})$. The total absorbed dose rate of the western zone is higher than the Worldwide average of 60 $(\mathrm{nGy} / \mathrm{h})$ compared with the middle and eastern zones which have low values.

\section{Effective dose.}

Effective dose is expressed in (sievert) and usually reported per annum. Dose assessment, therefore, requires knowledge of the type and amount of radiation and the biological sensitivity of the body part exposed. Because doses to workers and the public are so low, most reporting and dose measurements use the terms millisievert $(\mathrm{mSv})$ and microsievert $(\mu \mathrm{Sv})$ which are $1 / 1000$ and 1/1000000 of a sievert respectively. These smaller units of the sievert are more convenient to use in occupational and public settings.

\section{Outdoor effective dose.}

The annual effective doses are determined as follows according to, (UNSCEAR, 2000).

$\left\{\right.$ Eex, out $(\mathrm{mSv} / \mathrm{y})=\mathrm{Ab}$.Dose $\left(\mathrm{nGyh}^{-1}\right) \times 8760$ $\left.(\mathrm{h} / \mathrm{y}) \times 0.2 \times 0.7 \times 10^{-6}\right\}$

Time in hours for a year, [8760 (h/y)].

Occupancy factor for outdoor and indoor was $0.2(5 / 24)$ and $0.8(19 / 24)$ respectively implying that 80 of time is spent indoors on average around the world, (Veiga et al., 2006).

The conversion coefficient from absorbed dose in air to effective dose, (adults: 0.7, children: 0.8 and infants: 0.9), (UNSCEAR, 2000).

\section{Indoor effective dose.}

$\left\{\right.$ Eex, indoor $(\mathrm{mSv} / \mathrm{y})=\mathrm{Ab}$.Dose $\left(\mathrm{nGyh}^{\mathbf{- 1}}\right) \times 1.4$ x $\left.8760(\mathrm{~h} / \mathrm{y}) \times 0.8 \times 0.7 \times 10^{-6}\right\}$

Most building materials of terrestrial origin contain small amounts of NORM, mainly radionuclides from the Uranium-238 $\left({ }^{238} \mathrm{U}\right)$ and Thorium-232 $\left({ }^{\mathbf{2 3 2}} \mathrm{Th}\right)$ decay chains and the radioactive isotope of Potassium-40 $\left({ }^{40} \mathrm{~K}\right)$.

Past research efforts indicate that building materials represent an important natural source of radioactivity, because they come into closest contact with humans (UNSCEAR, 1993).

The ratios of indoor to outdoor exposures are ranged from 0.6 to 2.3 , with a population weighted value of 1.4, (UNSCEAR, 2000). The indoor exposures are $40 \%$ greater than the outdoor exposures.

The average effective dose from the radiation emitted from the soil (and the construction materials that come from the ground) is approximately $0.5 \mathrm{mSv}$ a year. (UNSCEAR, 2000).

\section{Total external effective dose.}

The total annual effective external dose $E_{\text {ex }}$, total $(\mathrm{mSv} / \mathrm{y})$ is the sum of $E_{\mathrm{ex}}$, out $(\mathrm{mSv} / \mathrm{y})$ and $E_{\text {ex }}$, indoor $(\mathrm{mSv} / \mathrm{y})$.

The average values of outdoor, indoor and total effective doses in $(\mathrm{mSv} / \mathrm{y})$ in study area along various square kilometers which arranged from west to east parallel to the shoreline and the corresponding zones are shown in Table (21). 
Table (21): The average values of outdoor, indoor and total effective doses in $(\mathrm{mSv} / \mathrm{y})$ in study area along various kilometers which arranged from west to east parallel to the shoreline and the corresponding zones.

\begin{tabular}{|c|c|c|c|c|c|c|c|}
\hline Area & 离 & \multicolumn{2}{|c|}{$\begin{array}{l}\text { Eex,out } \\
(\mathrm{mSv} / \mathrm{y})\end{array}$} & \multicolumn{2}{|c|}{$\begin{array}{l}\text { Eex,ind } \\
(\mathrm{mSv} / \mathrm{y})\end{array}$} & \multicolumn{2}{|c|}{$\begin{array}{c}\text { Eex,total } \\
(\mathrm{mSv} / \mathrm{y})\end{array}$} \\
\hline $1^{\text {st }}$ & \multirow{4}{*}{$\vec{y}^{\overrightarrow{3}}$} & 0.16 & \multirow{4}{*}{0.13} & 0.92 & \multirow{4}{*}{0.75} & 1.08 & \multirow{4}{*}{0.90} \\
\hline $2^{\text {nd }}$ & & 0.15 & & 0.84 & & 0.99 & \\
\hline $3^{\text {rd }}$ & & 0.12 & & 0.65 & & 0.77 & \\
\hline $4^{\text {th }}$ & & 0.08 & & 0.45 & & 0.53 & \\
\hline $5^{\text {th }}$ & \multirow{3}{*}{$\bar{z}$} & 0.05 & \multirow{3}{*}{0.04} & 0.29 & \multirow{3}{*}{0.21} & 0.35 & \multirow{3}{*}{0.25} \\
\hline $6^{\text {th }}$ & & 0.03 & & 0.18 & & 0.22 & \\
\hline $7^{\text {th }}$ & & 0.03 & & 0.15 & & 0.17 & \\
\hline $8^{\text {th }}$ & \multirow{3}{*}{ 馬 } & 0.04 & \multirow{3}{*}{0.05} & 0.24 & \multirow{3}{*}{0.30} & 0.29 & \multirow{3}{*}{0.35} \\
\hline $9^{\text {th }}$ & & 0.06 & & 0.32 & & 0.37 & \\
\hline $10^{\text {th }}$ & & 0.05 & & 0.30 & & 0.35 & \\
\hline Av & & \multicolumn{2}{|c|}{0.08} & \multicolumn{2}{|c|}{0.43} & \multicolumn{2}{|c|}{0.51} \\
\hline
\end{tabular}

The average values of Eex, out; Eex, ind and Eex, total in the study area are $0.08,0.43$ and $0.51(\mathrm{mSv} / \mathrm{y})$ respectively. The average effective dose from the radiation emitted from the beach sands (and the construction materials that come from it) is approximately $0.51 \mathrm{mSv}$ a year. It is obvious that our findings are in general agreement with the worldwide measured value (0.5) $\mathrm{mSv} /$ year, UNSCEAR (2000). So, the total effective dose rate remains in the safe side and within the maximum permissible safe radiation dose rate, without harm to the individual, except at the western zone ( 0.90 $\mathrm{mSv} / \mathrm{y})$. It is important to assess the radiation hazards arising due to the use of soil or sand samples in the construction of dwellings because the naturally occurring radionuclides decay to yield radon as one of their progenies. So the beach sands of the western zone $\left(4 \mathrm{Km}^{2}\right)$ are not recommended for use in building constructions because the inhabitants will receive relatively high radioactive doses, generated by monazite and radioactive zircon incorporated in the building materials. On the other hand, the average values of total effective dose in the middle and eastern zones are 0.25 $(\mathrm{mSv} / \mathrm{y})$ and $0.35(\mathrm{mSv} / \mathrm{y})$ respectively. Although the average values of total effective dose in the beach sands of the middle and eastern zones are lower than that in the western zone, it is not recommended for use in building constructions before extraction of the economic and strategic minerals from the beach sands especially the radioactive ones.

\section{SUMMARY AND CONCLUSIONS}

The study area located east of AbuKhashabah Village, Motobas Center, Kafr AlSheikh Governorate. It covers an area of about $10 \mathrm{Km}^{2}$, with $10 \mathrm{Km}$ long parallel to the shoreline and one kilometer width nearly perpendicular to the shoreline. The study area is bounded by the international highway to the south, Abu-Khashabah lighthouse asphaltic road to the west and El-Sahel (coastal) drain to the north.

The study area was covered by 306 samples to a depth of one meter at the intersection of a grid pattern $200 \mathrm{~m} \times 200 \mathrm{~m}$ nearly parallel and perpendicular to the shoreline. The collected samples in the study area were distributed along six profiles parallel to the shoreline. Every profile comprises 51 samples taken the symbol of the profile and numbered from 1 to 51 from west to east.

The apparent specific gravity of top meter sands varies from a minimum value of 1.29 $\mathrm{gm} / \mathrm{cm}^{3}$ to a maximum value of $1.74 \mathrm{gm} / \mathrm{cm}^{3}$ with an average value equal to $1.59 \mathrm{gm} / \mathrm{cm}^{3}$. The study area is divided to three zones according to apparent specific gravity; the western zone, $4 \mathrm{~km}^{2}\left(1.62 \mathrm{gm} / \mathrm{cm}^{3}\right)$; the middle zone, $3 \mathrm{~km}^{2}\left(1.58 \mathrm{gm} / \mathrm{cm}^{3}\right)$ and the eastern zone, $3 \mathrm{~km}^{2}\left(1.59 \mathrm{gm} / \mathrm{cm}^{3}\right)$.

The fines grain size (sizes finer than the coarse silt and organic materials) percentages vary from a minimum value of $0.72 \%$ to a maximum value of 74.08 with an average percent equal to $18.00 \%$. The eastern zone of study area contains the highest fines percentage $(20.11 \%)$ compared with the middle zone $(15.21 \%)$ or the western zone $(18.37 \%)$.

The grain size distribution of the field samples indicates that, the modal class lying in the fine sand size $(250 \mu-125 \mu)$.The weight percent of the modal class (fine sand fraction) ranges from $54.80 \%$ to $61.02 \%$ with an average $58.42 \%$.

The mean size $(\mathrm{Mz})$ of the raw sand sediments concentrated in two classes, the fine sand size class $(50.98 \%)$ and the very fine sand size class $(49.02 \%)$. The Inclusive graphic standard deviation, sorting $(\sigma 1)$, showed that most of the studied field samples located in the moderately sorted class $(94.12 \%)$ whereas $5.88 \%$ located in the moderately well sorted class. The Inclusive graphic Skewness, (Sk1), showed that most of the studied field samples located in the Extremely Fine Skewed (88.24\%) whereas $11.76 \%$ located in the Strongly Fine Skewed class. The Graphic kurtosis, $\left(K_{\mathrm{G}}\right)$ of the studied field samples distributed in four classes with a modal class located in the leptokurtic class $(56.86 \%)$, whereas $23.53 \%$ located in the mesokurtic class and $11.76 \%$ located in the very leptokurtic class.

The grain size parameters of, the studied sediments clear the source of these sediments from river environment, due to the high content of clay and organic matter in the raw sands. 
In the study area, the average values of economic minerals content along ten square kilometers and three zones arranged from west to east are $3.63 \%$. The tonnage of total economic minerals in the study area is 578760 ton. The tonnage of each individual economic mineral in the study area was calculated and tabulated as follows:

\begin{tabular}{|c|c|c|c|}
\hline $\begin{array}{c}\text { Economic } \\
\text { mineral }\end{array}$ & $\begin{array}{c}\text { Av .cont. } \\
\text { wt.\% }\end{array}$ & $\begin{array}{c}\text { Tonnage } \\
\text { Of raw sand } \\
\text { (tons) }\end{array}$ & $\begin{array}{c}\text { Reserve } \\
\text { (tons) }\end{array}$ \\
\hline Magnetite & 1.15 & & $\mathbf{1 8 2 , 8 5 0}$ \\
\hline Ilmenite & 2.07 & & 329,130 \\
\hline Garnet & $\mathbf{0 . 1 5}$ & & $\mathbf{2 3 , 8 5 0}$ \\
\hline Leucoxene & $\mathbf{0 . 0 9}$ & \multirow{2}{*}{15,900000} & $\mathbf{1 4 , 3 1 0}$ \\
\hline Zircon & $\mathbf{0 . 1 3}$ & $\mathbf{2 0 , 6 7 0}$ \\
\hline Rutile & $\mathbf{0 . 0 4 4}$ & & $\mathbf{6 , 9 9 6}$ \\
\hline Monazite & $\mathbf{0 . 0 0 6}$ & & $\mathbf{9 5 4}$ \\
\hline Total & $\mathbf{3 . 6 4}$ & & $\mathbf{5 7 8 , 7 6 0}$ \\
\hline
\end{tabular}

The average values of radiometric measurements along various square kilometers parallel to the shoreline from the first kilometer in the west to the tenth kilometer in the east which divided into three zones are calculated and tabulated as follows: maximum permissible safe radiation dose rate, without harm to the individual, except at the western zone $(0.90 \mathrm{mSv} / \mathrm{y})$.

So the beach sands of the western zone (4 $\mathrm{Km}^{2}$ ) are not recommended for use in building constructions because the inhabitants will receive relatively high radioactive doses, generated by monazite and radioactive zircon incorporated in the building materials.

On the other hand, the average values of total effective dose in the middle and eastern zones are $0.25(\mathrm{mSv} / \mathrm{y})$ and $0.35(\mathrm{mSv} / \mathrm{y})$ respectively. Although the average values of total effective dose in the beach sands of the middle and eastern zones are lower than that in the western zone, it is not recommended for use in building constructions before extraction of the economic and strategic minerals from the beach sands especially the radioactive ones.

\section{REFERENCES}

Abdel-Fattah, M. F. (2008): Evaluation, beneficiation and mineralogy of the Egyptian beach leucoxene in $\mathrm{Abu}$ Khashaba area, east Rosetta, Egypt. M.Sc. Thesis, Fac.Sci. Zagazig University, Egypt. Abu-Diab, A.A. (2008): Characters and distribution of the economic minerals in the black sand deposits of the coastal area, west El-Burullus, Egypt and their sedimentation condition. Ph.D. Thesis, Fac. Sci., Ain Shams University.

Abu Halawa, A. (2005): Evaluation and mineral processing of some economic minerals in El Burullus - Baltim sand dunes, Nile Delta, Egypt. Ph.D. Thesis, Fac. Sci., El Mansoura University, Egypt.

mmar, A.A.; Sharaky, A.M.; Shahein, A.N.; El-Sadek, M.A. and El-Khateeb, S.A. (2005): Radiolithologic studies on beach and alluvial black sand deposits, Koam Mashaal area, Egypt, using ground radiospectrometry. In proceeding of the first international conference on the Geology of Tethgs, Vol. 1, pp.125-136.

Barakat, M.G. (2004): Sedimentological studies and evaluation of some black sands deposits on the northern coast of Egypt. M.Sc. Thesis, Fac.Sci. Alexandria University, Egypt, 176 p.

Burt, R.O. (1984): Gravity concentration technology. Elsevier Science Publishers B.V., Amestrdam, the Netherlands, 605 p.

Dabbour, G.A. (1973): Physical properties and distribution of zircon in some Egyptian placer deposits. M.Sc. Thesis, Fac. Sci., Cairo University, Egypt.

Dabbour, G.A. (1980): Geological and mineralogical studies on rutile in the black
UNSCEAR (2000). So, the total effective dose rate remains in the safe side and within the 
sand deposits from the Egyptian Mediterranean coast. Ph.D. Thesis, Fac. Sci., Cairo University, Egypt, 155 p.

Dabbour, G.A. (1991): Heavy minerals content in relation to the apparent specific gravity of the Egyptian black sands. Bull., Fac. Sci., EL Mansoura University, Special Issue, pp. $212-220$.

Dabbour, G.A. (1994): The Egyptian placer deposits: a potential source for Nuclear Raw Materials. $2^{\text {nd }}$ Arab Conference on the Peaceful Uses of Atomic Energy, Cairo, pp. $191-204$

Dabbour, G.A. (1995): Estimation of the economic minerals reserves in Rosetta beach sands, Egypt. Mineral. Vol. 7, pp. $1532-166$.

Dabbour, G.A. (1997): Mineralogical study on the opaque minerals and secondary rutile from the Egyptian black sands. Proceed. Egypt. Acad. Sci., Vol.47, pp.105-121

Dewedar, A.A. (1997): Comparative studies on the heavy minerals in some blach sands deposits from Sinai and east Rosetta with contribution to the mineralogy and economics of their garnets. Ph.D. Thesis, Fac. Sci., El Menoufia University, Shebin El Koum, Egypt, 197 p.

El-Gamal, A.; Saleh, I.; Nasr, S. and Naim, M. (2004): Radiological assessment of the Egyptian Mediterranean coast. International conference on isotopes in environmental studies. Aquatic forum 2004, Monte. Cairo, Monaco, 25-29October 2004, IAEA-CN118\31P, PP. 396-397.

El-Gamal, A.A. and Saleh, I.H. (2012): Radiological and mineralogical investigation of accretion and erosion coastal sediments in Nile Delta region, Egypt. Journal of oceanography and Marine Science, Vol. 3, Issu. 3, pp. 41-55.

El-Hadary, A.F. (1998): Geological, sedimentological and radiometric studies on the black sand deposits, west Rosetta beach with emphasis on the heavy economic minerals. Ph.D. Thesis, Fac. Sci., Cairo Univ., Egypt.

El-Nahas, H.A. (2002): Mineralogy, evaluation and upgrading studies on some economic minerals in beach black sands. El Arish area, Egypt. M.Sc. Thesis, Fac. Sci., El Minufiya University, Egypt, 162 p.

El-Shafey, A.M. (2011): Mineralogical, evaluation and beneficiation of the economic minerals of Egyptian black sands especially Cassiterite, in Abu-Khashaba area, east Rosetta, Egypt. M.Sc. Thesis, Fac. Sci. Zagazig University.

El-Shazly, E.M. (1965): Thorium resources in the United Arab Republic and their possible utilization. Panel on utilization of Th in Power Reactors, IAEA, Vienna, pp.186198.

Friedman, G.M. (1961): Distinction between dune, beach and river sand from their textural characteristics. J. Sed. Petro., Vol. 31 , pp. $514-529$.

Friedman, G.M. (1967): Dynamic Processes and statistical parameters compared for size frequency distribution of beach and river sands. J. Sed. Pet. Vol. 37, No. 2, pp. 327351.

Hammoud, N.M.S. (1966): Concentration of monazite from Egyptian black sands employing industrial techniques. M.Sc. Thesis, Fac. Sci., Cairo University, Cairo, Egypt. 198 p.

Hammoud, N.S. (1985): Contribution to the evaluation problems of Egyptian beach economic minerals. Annals of Geol. Sur. of Egypt, vol.15, p.45-59.

Inman, D.L. (1949): Sorting of sediments in light of fluvial mechanics. J. Sed. Petro., Vol. 19, pp. $51-70$.

Kelly, E.G. and Spottiswood, D.J. (1989): The theory of electrostatic separations: a review, Part I. Fundamentals. Minerals Eng. Vol.2, No.1, pp.33-46.

Lawver, J.E; Taylor, J.B. and Knoll, F.S. (1986): Laboratory testing for electrostatic concentration circuit design. SME-AIME Annual Meeting, March, pp.454-477.

Martin, L.R. (1965): Significance of skewness and kurtosis as environmental interpretation. J. Sed. Petro., Vol. 34, pp. $768-770$.

Mason, C.C. and Folk, R.L. (1958) : Differentiation of beach, dune and aeolian flat environments by size analysis, Mustange Island, Texas. J. Sed. Petro., Vol. 28 , pp. $211-226$.

Moiola, R.J. and Weisser, D. (1968): Textural parameters: An evaluation. J. Sed. Petro., Vol. 38, pp. 45 - 53.

Moustafa, M.I. (1999): Mineralogy and beneficiation of economic minerals in the Egyptian black sands. Ph.D. Thesis, Fac. Sci., El Mansoura University, El Mansoura, Egypt, 316 p.

Moustafa, M.I. (2007): Separation flow sheet for high purity concentrates of some Ec. Min. from El-Burullus Baltim sand Dunes Area, North coast, Egypt. The fifth international conference on the geology of Africa, Vol. 1, pp. 111-124.

Moustafa, M. I. (2009): Mineralogical and geochemical studies on monazite - Th, REE silicate series in the Egyptian beach monazite concentrate. Sedimentology of Egypt, Vol. 17, pp. 63-88. 
Moustafa, M.I. (2010): Mineralogical characteristics of the separated magnetic rutile of the Egyptian black sands. Resource geology, Vol. 60, Issue, 3, pp. 300-312.

Naser, S.; El-Gamal, A.; Hendawi, I. and Naim, M. (2006): Statistical evaluation of natural radio activity in sediments along the Egyptian Mediterranean coast. Proceeding of the $2^{\text {nd }}$ environmental physics conference, pp. 161-166.

Nordstrom, K.F. (1977): The use of grain size statistics to distinguish between high and moderate energy beach environment. J. Sed. Petro., Vol. 47, pp. 1287-1294.

Passega, R. (1964): Grain sizer representation by C-M patterns as a geological tool. J. Sed. Petro., Vol. 34, pp. 830 - 847.

Passega, R. and Byramjee, R. (1964): Grain size image of clastic deposits. Sedimentology, Vol. 13, pp. $233-252$.

Pettijohn, F. J. (1975): Sedimentary rocks, $3^{\text {rd }}$ Ed., Harper and Row Publ, New York.

Rajamanickam, G.V. and Gujar, A.R. (1984): Sediment depositional environment in some bays in the central west coast of India. In. Jour. Mar. Sci, Vol. 13, pp. 53-59.

Rajamanickam, G.V. and Gujar, A.R. (1997): Grain size studies on the near shore sediment of Jaigad, Ambwah and varvada Bays, Maharashtra. Journal Geological society of India, Vol.49, pp. 567-576.

Robertson Research International (RRI) Limited (1985): An appraisal of the Rosetta black sands deposit. The Nuclear Materials Corporation, Internal Report, No. 4071, Cairo, Egypt.

Sadek, H.S.; Soliman, S.A.; Abdelhadi, H.M. and Hosni, A.A. (1990): Geophysical exploration of the black sands at $\mathrm{Abu}$ Khashaba beach, Rosetta coast: Internal Report, NMA, Cairo, Egypt.

Sahu, B.K. (1964): Depositional mechanisms from the size analysis of clastic sediments. J. Sed. Petro., Vol 34, pp. 73 - 83 Said. R.
(1981): The geological evolution of the River Nile. Springier- Verlag Inc., New York.

Saleh, I.; El-Gamal, A.; Nasr, S. and Naim, M. (2004): Spatial and temporal variations of uranium and thorium series along the Egyptian Mediterranean coast. International conference on isotopes in environmental studies. Aquatic forum 2004, Monte- Cairo, Monaco, 25-29 October 2004, IAEA- CN$118 \backslash 113$ P, PP. 550-551.

Sevon, W.D. (1966): Distribution of New Zeeland beach, dune and river sands by their grain size distribution curves. New Zeeland J. Geol. Geophys., Vol. 9, pp. 212 -223 .

Shepard, F.P. and Young, R. (1961): Distinguish between beach and dune sands. J. Sed. Petro., Vol. 31, pp. $196-214$.

UNSCEAR (1988) Sources and biological effects. Report to the General Assembly of the United Nations with Scientific Annexes, United Nations sales publication E.82.IX.8, New York.

UNSCEAR (1993): Sources and effects of ionizing radiation. Report to General Assembly of the United Nations with Scientific Annexes, United Nations the sales publication E.94.IX.2, New York.

UNSCEAR (2000): Sources and effects of ionizing radiation. Report to the General Assembly of the United Nations with Scientific Annexes, United Nations sales publication E.00.IX.3, New York.

Veiga, R. G., Sanches, N., Anjos, R., Macario, K., Bastos, J., Iguatemy, M., Auiar, J. G., Mosquera, B., Carvalho, C., BaptistaFilho, M., and Umisedo, N. K., (200): Measurement of natural radioactivity in Brazilian beach sands. Radiation Measurements, 41 189-196.

Visher, G.S. (1969): Grain size distribution and depositional processes. J. Sed. Petro., Vol. 39, pp. $1074-1106$. 